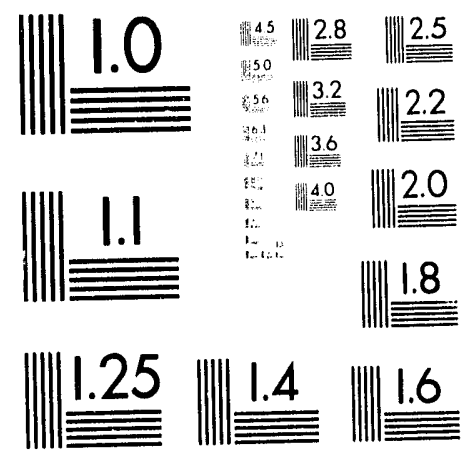



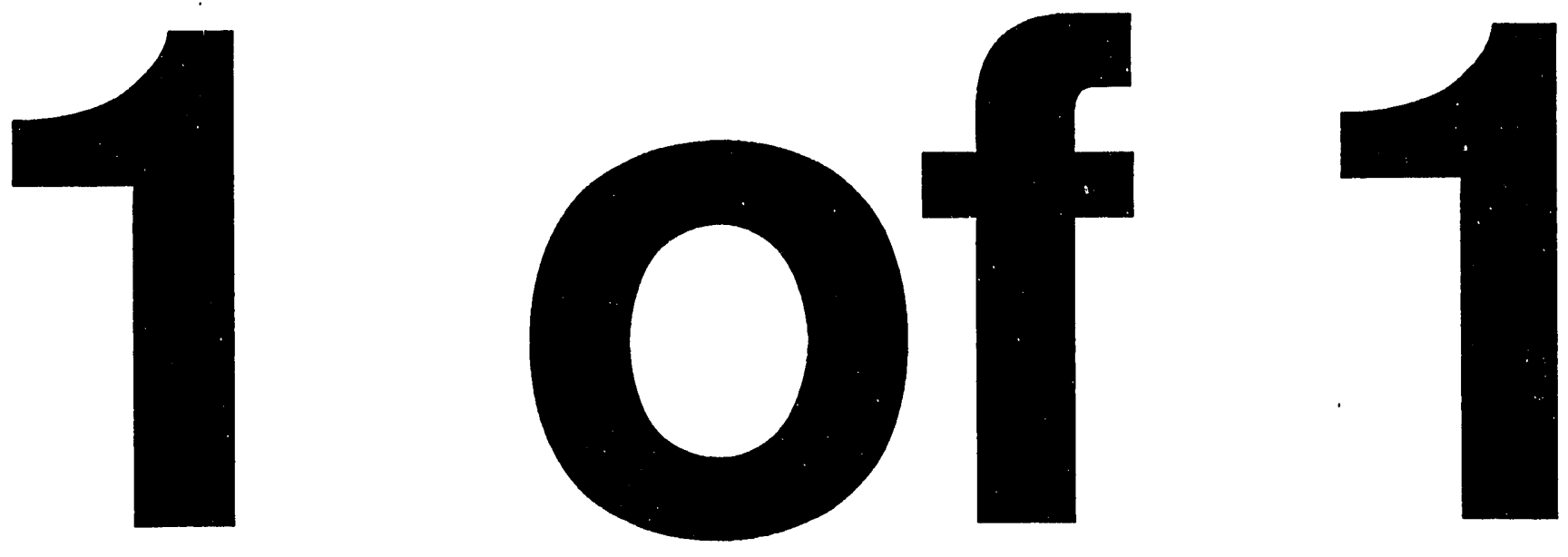


\title{
STUDY OF IMPROVED METHODS FOR PREDICTING
}

\section{CHEMICAL EQUILIBRIA}

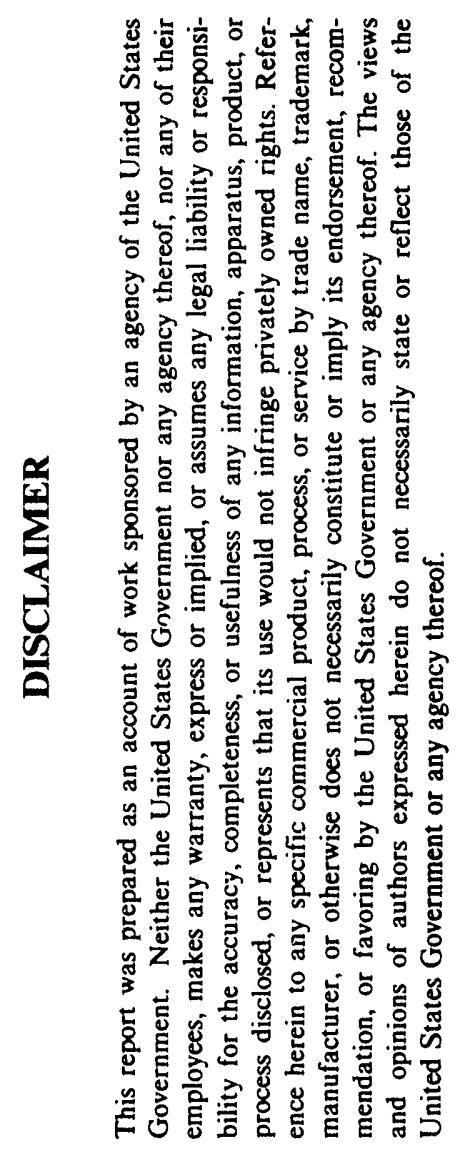

\author{
Final Report \\ for Period January 1, 1990 - March 31, 1993 \\ Terry G. Lenz \\ Department of Chemical Engineering \\ and
}

John D. Vaughan

Department of Chemistry

Colorado State University

Fort Collins, CO 80523

September 1993

Prepared for

THE U.S. DEPARTMENT OF ENERGY

AGREEMENT NO. DE-FG02-86ER13582 
TABLE OF CONTENTS

\section{Page}

I. General Background

II. Computational Modeling Progress

A. Thermodynamic Function and zero-point Energy 4

B. Standard Enthalpies of Formation 5

C. Dihedral Driver 7

D. Hindered Internal Rotation 8

E. 1,3-Butadiene 8

F. Heteroatomic Capability of QCFF/PI 9

G. Summary and Conclusions 10

III. Experimental studies 11

A. Energy of Combustion of DAAMA 11

B. X-Ray Crystal structure of the DAAMA 12

C. Vapor Pressure and Enthalpy of sublimation
of DAAMA

D. Energies of Combustion of $4 \mathrm{MCH}$ and $4 \mathrm{VCH} \quad 14$

E. Vapor Pressures and Enthalphies of Vaporization of $4 \mathrm{MCH}$ and $4 \mathrm{VCH}$

References $\quad 29$

IV. Appendix

Further Progress with Torsional Functions -

Calculations for 2-Methyl-1,3 Butadiene 


\section{General Bacistound}

The objective of our research during the two preceding and current periods has been to develop computational methods that have the capability of accurately predicting equilibrium constants of typical organic reactions in gas and liquid solution phases. We have chosen Diels-Alder reactions as prototypic systems for the investigation, chiefly because there are an adequate number of reported equilibrium constants ${ }^{1}$ for the candidate reactions in both gas and solution phases, which data provides a suitable basis for tests of the developed computational methods. Our approach has been to calculate the standard enthalpies of formation $\left(\Delta \mathrm{H}_{\mathrm{f}}^{\mathrm{O}}\right)$ at $298.15 \mathrm{~K}$ and the standard thermodynamic functions $\left(\mathrm{S}^{\circ}\right.$, $\mathrm{CP}^{0}$, and $\left.\left(\mathrm{H}^{\mathrm{O}}-\mathrm{H}_{\mathrm{O}}^{\mathrm{O}}\right) / \mathrm{T}\right)$ for a range of temperatures for reactants and products, and from these properties to calculate standard enthalpies, entropies, Gibbs free energies, and equilibrium constants $\left(\Delta \mathrm{H}_{\mathrm{T}}^{\mathrm{o}}, \Delta \mathrm{S}_{\mathrm{T}}^{\mathrm{o}}, \Delta \mathrm{G}_{\mathrm{T}}^{\mathrm{o}}\right.$, and $\left.\mathrm{K}_{\mathrm{a}}\right)$ at various temperatures for the chosen reaction. A summary of the refereed papers resulting from work carried out under this project is given in Table 1. Our specific research to date has proceeded along the following pathways:

(1) Development of molecular mechanics programs capable of calculating $\Delta \mathrm{H}_{\mathrm{f}}^{\mathrm{O}}$, $\underline{\mathrm{S}}^{\mathrm{O}}, \mathrm{Cp}^{\mathrm{O}}$, and $\left(\mathrm{H}^{\mathrm{O}}=\mathrm{H}_{\mathrm{O}}^{\mathrm{O}}\right) \mathrm{TT}$ for gas phase reactants and products. During past periods, we employed existing molecular mechanics programs to calculate equilibrium constants over a wide temperature range for Diels-Alder dimerizations of 1,3-cyclopentadiene ${ }^{2}$ and 1,3-butadiene, ${ }^{3}$ respectively, and Diels-Alder condensations of 1,3-cyclopentadiene with acetylene ${ }^{4}$ and ethylene ${ }^{4}$ and of 1,3butadiene with ethylene. ${ }^{3}$ The excellent agreement between calculated and literature equilibrium constant values clearly indicated that molecular mechanics can provide an accurate and potentially general method for predicting equilibrium properties of gas phase reactions. However, the molecular mechanics programs 
that were used (MOLBD3 $3^{2,4,5}, \mathrm{MMP}^{3,6}$ and $\mathrm{QCFF} / \mathrm{PI}^{3,7}$ ) each have distinct limitations in their applicability to specific reactants and products. Thus, MMP2 can compute $\Delta \mathrm{H}_{\mathrm{f}}^{\mathrm{O}}$ for saturated, unsaturated, aromatic, and heteroatomic organic compounds, but cannot compute their thermodynamic functions, QCFF/PI thermodynamic functions ${ }^{8}$ for hydrocarbons (including aromatics) but not $\Delta \mathrm{H}_{\mathrm{f}}^{\mathrm{o}}$, while MOLBD3 can calculate $\Delta H_{f}^{o}$ and thermodynamic functions for hydrocarbons except the highly important class of aromatics. Accordingly, the major thrust in the development of a gas phase computation method has been to modify one of these programs, QCFF/PI, into a general thermodynamic molecular mechanics program that can compute $\Delta \mathrm{H}_{\mathrm{f}}^{\mathrm{O}}, \mathrm{S}^{\mathrm{o}}, \mathrm{C}_{\mathrm{p}}^{\mathrm{o}}$, and $\left(\mathrm{H}^{\mathrm{O}}-\mathrm{H}_{\mathrm{o}}^{\mathrm{O}}\right) / \mathrm{T}$ for saturated hydrocarbons, unsaturated -enes and -dienes, and aromatic hydrocarbons, and a variety of oxygen, nitrogen, and other heteroatomic compounds.

(2) Transformation of gas phase $\Delta \mathrm{H}_{\mathrm{f}}^{0}$ and $\mathrm{S}^{\circ}$ properties of reactants and products into corresponding condensed phase properties, by use of standard enthalpies of vaporization $\left(\Delta \mathrm{H}_{\mathrm{V}}^{\mathrm{O}}\right.$ or sublimation $\Delta \mathrm{H}_{\mathrm{S}}^{\mathrm{O}}$ ). The procedure here is to calculate $\Delta \mathrm{G}_{\mathrm{T}}^{\mathrm{o}}$ and hence $\mathrm{K}_{\mathrm{a}}$ for a reaction. ${ }^{9}$ This procedure was successfully applied in our 1,3-cyclopentadiene dimerization study, ${ }^{2}$ using literature vapor pressure data ${ }^{10}$ for monomer and dimer for the reaction in paraffin and in endodicyclopentadiene solutions. In those instances where literature vapor or sublimation pressure data are not available, our approach is to determine these data in the laboratory. A future goal is to develop reliable methods for predicting vapor or sublimation pressures of typical reactants and products for a range of temperatures, from which $\Delta \mathrm{H}_{\mathrm{v}}^{0}$ or $\Delta \mathrm{H}_{\mathrm{S}}^{\mathrm{o}}$ can be calculated.

(3) Experimental determination of X-ray crystal structures for large reactants and products (such as substituted anthracene dienes and their Diels-Alder adducts 
with maleic anhydride). Crystallographic bond lengths, bond angles, dihedral angles, and nonbonded distances between atomic pairs provide a valuable test for the accuracy of calculations of these data by molecular-mechanics programs. substituted anthracene dienes and their adducts with maleic anhydride). ${ }^{11} \Delta \mathrm{H}_{\mathrm{f}}^{\mathrm{O}}$ for the gas phase can be determined from the calorimetric $\Delta \mathrm{H}_{\mathrm{f}}^{\mathrm{O}}$ for the solid or liquid compound plus $\Delta \mathrm{H}_{\mathrm{S}}^{\mathrm{O}}$ or $\Delta \mathrm{H}_{\mathrm{v}}^{\mathrm{O}}$, providing a further test for our molecular mechanics programs.

\section{Computational Modeling Progress}

The original QCFF/PI program ${ }^{7}$ was capable of calculating vibrational frequencies and predicting structures of saturated and unsaturated hydrocarbon molecules that agreed well with the literature. ${ }^{3,7}$ Additionally, the energy of a molecule at rest at absolute zero $\left(E_{\mathrm{T}}\right)$ was calculated as was the zero-point energy, but the thermodynamic functions $S^{\circ}, C_{p}^{O}$, and $\left(\mathrm{H}^{\circ}-\mathrm{H}_{\mathrm{O}}^{\mathrm{O}}\right) / \mathrm{T}$ were not, nor was $\Delta \mathrm{H}_{\mathrm{f}}^{\mathrm{O}}$. Hence, the original program was limited to comparisons of the relative stabilities of molecules. We selected QCFF/PI for development into a general thermodynamic program, despite its limitations, principally because of (1) its capability of treating unsaturated and aromatic molecules effectively, (2) the relatively good accuracy of its vibrational frequency calculations, and (3) the relative ease in modifying its potential energy functions. Accordingly, our goal in the modification of the program was to develop algorithms for calculating the thermodynamic functions and $\Delta \mathrm{H}_{\mathrm{f}}^{\mathrm{O}}$, with accuracy limits of less than $\pm 1 \mathrm{cal} / \mathrm{mol} \mathrm{K}$ and $\pm 1 \mathrm{kcal} / \mathrm{mol} \mathrm{K}$, resfectively.

A. Thermodynamic Functions and Zero-Point Energy. A subprogram that computes thermodynamic functions of molecules from QCFF/PI-calculated atomic coordinates and vibrational frequencies was incorporated into QCFF/PI during an earlier period. ${ }^{12}$ However, calculated ZPE values of typical hydrocarbons were invariably high, 
and correspondingly, $\mathrm{S}^{\mathrm{O}}, \mathrm{Cp}^{0}$, and $\left(\mathrm{H}^{\mathrm{O}}-\mathrm{H}_{\mathrm{O}}^{\mathrm{O}}\right) / \mathrm{T}$ values were therefore generally low. For example, ZPE for cyclohexadiene calculated by QCFF/PI using original (default) parameters was $76.1 \mathrm{kcal} / \mathrm{mol}, \mathrm{S}^{\circ}$ was $71.9 \mathrm{cal} / \mathrm{mol} \mathrm{K}$, and $\mathrm{Cp}^{0} 21.5 \mathrm{cal} / \mathrm{mol} \mathrm{K}$; corresponding literature values ${ }^{13}$ were $73.9,72.5$, and 22.5 , respectively. These systematic errors resulted from individual vibrational frequencies that were calculated to be slightly too high (on average), that produced cumulatively the observed high ZPE and low thermodynamic function values. To correct the problem, we reduced slightly individual bond-stretch parameters, bond angle-bend parameters, and torsion parameters systematically. These alterations resulted in ZPE and thermodynamic functions that exhibited generally better agreement with literature values without affecting predicted structures significantly. Sample calculated and literature results for several chemicallyinteresting cycloalkenes, cycloalkadienes, and aromatic compounds are shown in Table 2; the altered parameters are given together with the original ones in Table 3.

B. Standard Enthalpies of Formation. This important quantity is calculated by the ' following equation ${ }^{5}$

$$
\Delta \mathrm{H}_{\mathrm{f}}^{\mathrm{O}}=\mathrm{E}_{\mathrm{T}}+\mathrm{ZPE}+\left(\mathrm{H}_{298}^{\mathrm{O}}-\mathrm{H}_{\mathrm{O}}^{\mathrm{O}}\right)+179.89 \mathrm{a}+52.09 \mathrm{~b}+(5 / 2)(\mathrm{a}+\mathrm{b}) \mathrm{R}(298.15)
$$

where $E_{T}$ is the QCFF/PI-calculated energy of the molecule $\mathrm{C}_{\mathrm{a}} \mathrm{H}_{\mathrm{b}}$, $\left(\mathrm{H}_{298}^{\mathrm{O}}-\mathrm{H}_{\mathrm{O}}^{\mathrm{O}}\right)$ the enthalpy function at $298.15 \mathrm{~K}, 170.89$ and $2(52.09)$ the atomization enthalpies of graphite and $\mathrm{H}_{2}$ (g) at 298.15 , respectively, and $\mathrm{R}$ the gas constant. $\mathrm{E}_{\mathrm{T}}$ is given by the equation ${ }^{5}$

$$
E_{T}=\left(\sum_{i}^{\text {bonds }} E_{i}\right)-(D E+N B)
$$

where $E_{i}$ is the ith bond energy parameter, DE the sum of bond stretch, bond angle bend, and bond torsion energies, and NB the sum of nonbonded energies.

After optimizing ZPE (described in A), our initial attempts to calculate accurate $\Delta \mathrm{H}_{\mathrm{f}}^{\mathrm{O}}$ values by adjusting the $E_{i}$ parameters for the various carbon-carbon single and double 
bonds, and for $\mathrm{Csp}^{3}-\mathrm{H}$ and $\mathrm{Csp}^{2}-\mathrm{H}$ bonds, were not successful. In particular, energy differences $\Delta \mathrm{E}_{\mathrm{T}}$ between rotomers, sterioisomers, and homologous series members were often not accurately predicted. For example, $\Delta \mathrm{E}_{\mathrm{T}}$ at $298 \mathrm{~K}$ for the cisoid and transoid conformers of 1,3-butadiene was calculated to be $0.5 \mathrm{kcal} / \mathrm{mol}$, compared to the literature value ${ }^{16}$ of $2.7 \mathrm{kcal} / \mathrm{mol}$. It appeared likely that the incorrect $\Delta \mathrm{E}_{\mathrm{T}}$ values found for the various structural isomers resulted chiefly from incorrect torsional potential functions. Accordingly, we added supplemental torsional potential functions to existing torsional functions for certain carbon-carbon bonds. Two supplemental torsional functions were found to produce accurate $\Delta E_{\mathrm{T}}$ values:

$$
\begin{aligned}
\mathrm{F}(\phi)= & \mathrm{CX}(1+\cos \phi)+\mathrm{CY}(1+\cos 2 \phi)+ \\
& \mathrm{CZ}(1+\cos 3 \phi)+\mathrm{CW}(1+\cos 4 \phi) \\
\mathrm{F}(\phi)= & \mathrm{CX}(\mathrm{CY}+\cos \phi)-\mathrm{CZ}(1-\cos 2 \phi)(1+\mathrm{CW} \cos \phi)+ \\
& \mathrm{CXA}(1-\cos \phi)
\end{aligned}
$$

where $\phi$ is the torsional (dihedral) angle for a given linear group of four bonded carbon atoms ( $\mathrm{C}-\mathrm{C}-\mathrm{C}-\mathrm{C}$ ). Equation (3) was applied to the central atomic pair in the following bonded groups:

$$
\begin{array}{ll}
\mathrm{Csp}^{3} \mathrm{Csp}^{2} \mathrm{Csp}^{2} \mathrm{Csp}^{3} & \text { alkenes } \\
\mathrm{Csp}^{2} \mathrm{Csp}^{2} \mathrm{Csp}^{3} \mathrm{Csp}^{3} & \left\{\begin{array}{l}
\text { alkenes, } \\
\text { alkadienes }
\end{array}\right. \\
\mathrm{XCsp}{ }^{3} \mathrm{Csp}^{3} \mathrm{Y} & \text { bridged hydrocarbons }
\end{array}
$$

where $\mathrm{X}$ refers to $\mathrm{Csp}^{2}$ or $\mathrm{Csp}^{3}$ and $\mathrm{Y}$ specifically to a bridgehead $\mathrm{Csp}^{3}$; for example, norbornadiene, $\mathrm{X}$ is $\mathrm{Csp}^{2}$. 


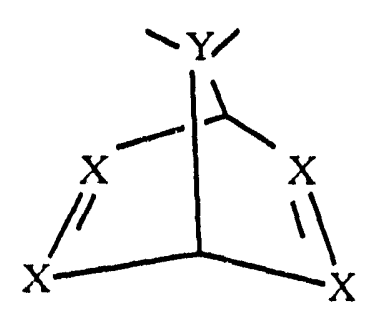

Equation (4) was applied to the central bond in $\mathrm{Csp}^{2} \mathrm{Csp}^{2} \mathrm{Csp}^{2} \mathrm{Csp}^{2}$ linkages in 1,3-dienes and in aromatic compounds. The $\mathrm{CX}, \mathrm{CY}, \mathrm{CZ}$ and $\mathrm{CW}$ torsional parameters in equation (3) were adjusted to give accurate energy separations in conformers (for example, two 1-butene conformers and two cyclohexene conformers), and in equation (4) for dienes tc give accurate energy separations of the trans, gauche, and cis conformers of 1,3-butadiene, and to accurately predict the barrier to internal rotation around the central $\left(\mathrm{Csp}^{2}-\mathrm{Csp}^{2}\right)$ bond. For aromatic compounds, the parameters were adjusted to yield good estimates of $\Delta \mathrm{H}_{\mathrm{f}}^{0}$ for benzene, naphthalene, and anthracene.

Table 4 lists $\mathrm{QCFF} / \mathrm{PI}$ - calculated $\Delta \mathrm{H}_{\mathrm{f}}^{\mathrm{O}}$ values for typical alkenes, alkadienes, and aromatics; MMP2 and observed values are given for comparison. Table 5 lists CX, CY, $\mathrm{CZ}$, and $\mathrm{CW}$ parameters that were used in the calculations. No supplemental terms were required for $\mathrm{X} \mathrm{Csp}^{3} \mathrm{Csp}^{3} \mathrm{X}$ torsions (provided $\mathrm{X}$ was not a bridgehead $\mathrm{Csp}^{3}$ atom). Table 6 lists QCFF- and MMP2-calculated $\Delta \mathrm{H}_{\mathrm{f}}^{0}$ values for specific alkane conformers; the observed values in Table 6 pertain to mixtures of conformers, except in those instances where there is but one.

C. Dihedral Driver. A dihedral driver subroutine was written into QCFF/PI, that rotates atomic coordinates around a selected bond, thereby locating maxima and minima in the torsional potential energy function of the bond. Hence, conformers (rotomers) are located, the energy of each computed, and barriers to internal rotations determined. This addition to the program, together with the introduction of supplemental torsional terms, resulted in significantly improved energy differences of conformers, barriers to internal rotation, and torsional contributions to molecular energy and to the thermodynamic functions. 
D. Hindered Internal Rotation. The contribution of hindered internal rotation to the thermodynamic functions is negligible at room temperature in most instances, but can become inore significant as temperature increases, and becomes especially so if the barrier to internal rotation is small. The effects of hindered internal rotation can be readily seen by the thermodynamic functions of trans-and cis-2-butene. The barrier to internal rotation in the trans-isomer has been estimated ${ }^{18}$ to be $1950 \mathrm{kcal} / \mathrm{mole}$ for each methyl group, but that for the cis-isomer to be only $450 \mathrm{kcal} / \mathrm{mol}$. The thermodynamic functions, calculated with and without hindered internal rotational contributions, are given in Table 7. The Halford adaptation ${ }^{19}$ of Pitzer's method ${ }^{20}$ was used to calculate the hindered internal rotational contributions. The results indicate that hindered internal rotation should be included for methyl-sutstituted compounds, particularly if pairs of methyl carbon atoms bonded to adjacent carbon atoms are mutually eclipsed. The Halford calculation is easily integrated into $\mathrm{QCFF} / \mathrm{PI}$; one requires the barrier to internal rotation $\left(\mathrm{V}_{0}\right)$ and the reduced moment of inertia $\left(\mathrm{I}_{\mathrm{r}}\right)$, together with a table ${ }^{19}$ of hindered internal rotational increments to $\mathrm{S}^{\circ}, \mathrm{Cp}^{\circ}$, and $\left(\mathrm{H}^{\mathrm{O}}-\mathrm{H}_{\mathrm{O}}^{0}\right) / \mathrm{T} . \mathrm{V}_{\mathrm{o}}$ is determined by application of the dihedral driver; $\mathrm{I}_{\mathrm{r}}$ is calculated from QCFF/PI - calculated principal moments of inertia and direction cosines by use of an equation given by Pitzer and Guinn. ${ }^{20}$ Although procedural details have been worked out, we have not completed the necessary software changes at this time.

E. 1,3-Butadiene. A limit to the effectiveness of molecular mechanics programs is the accuracy of experimental thermodynamic and structural data for prototypic molecules that are used to calibrate the programs. This consideration becomes increasingly important as molecular mechanics programs become more sophisticated and capable of greater accuracy. This point is illustrated by 1,3-butadiene which along with benzene and ethylene, is used in parameter determinations in molecular mechanics programs that treat conjugated pi systems. At temperatures below $425 \mathrm{~K}$, thermodynamic properties determined calorimetrically ${ }^{21}$ for 
mixtures of trans and other conformers are generally accepted to be accurate. However, the mole fractions of the mixtures, based on early spectral data ${ }^{22}$ and the incorrect assumption that only trans and cis conformers exist, are accordingly not correct. More recently, Bock and co-workers, ${ }^{16}$ using later more accurate spectral data, determined that 1,3-butadiene consists of trans-, sterioisomeric gauche-, and cis- conformers. Since 1,3-acyclic and cyclic dienes are of considerable importance in general and specifically in our research, and since QCFF/PI (as well as other molecular mechanics programs) fail to detect a stable gauche form, we determined to adjust the parameters of equation (4) such that QCFF/PI mimics the Bock et al. ${ }^{16}$ torsional profile. The result of the parameter adjustment is shown in Figure 1 (for CX, CY, CZ, and CW values listed in Table 5 for 1,3-dienes). The excellent agreement between the QCFF/PI calculated energies and the Bock et al. energies indicates that equation (4) is very well suited for 1,3-dienes. That the parameters found for 1,3butadiene are transferable is evident from the good agreement of calculated $\Delta H_{\mathrm{f}}^{0}$ values of other 1,3-dienes with observed values (Table 4).

F. Heteroatomic Capability of QCFF/PI. The original QCFF/PI program was equipped with potential functions and parameters for keto-oxygen and pyrrole-type nitrogen heteroatoms. We tested the former by comparing calculated structural details (calculated bond lengths, bond angles, and dihedral angles) of ethanal and propanal with MMP2 results, and calculated thermodynamic functions with corresponding literature values. The QCFF/PI- calculated molecular geometry agreed well with MMP2. However, the calculated entropies were unacceptably low. We introduced necessary changes in the $\Delta \mathrm{H}_{\mathrm{f}}^{\mathrm{O}}$ - algorithm to accommodate keto-oxygen with poor success. Considerable refining of both potential functions and parameters is required for the keto-oxygen heteroatom, similar to the refinements already applied to hydrocarbons, but will also include addition of potential functions for electrostatic interactions, currently not included in the program. In addition, 
potential functions for alkoxy-, ether-, and alcohol-oxygen, for azole-type nitrogen, and for halogen heteroatoms, will be included in the program.

G. Summary and Conclusions. At this time, our development of a molecular mechanics program capable of calculating thermodynamic properties $\Delta \mathrm{H}_{\mathrm{f}}^{\mathrm{O}}, \mathrm{S}^{\mathrm{O}}, \mathrm{Cp}^{\mathrm{O}}$, and $\left(\mathrm{H}^{0}-\mathrm{H}_{\mathrm{o}}^{0}\right) / \mathrm{T}$ for gas phase hydrocarbons from the original QCFF/PI (QCPE 534) is nearly complete. Currently, the program can compute these properties typically with accuracy limits of $\Delta \mathrm{H}_{\mathrm{f}}^{0}$ less than $\pm 1 \mathrm{kcal} \mathrm{mol}^{-1}$ and thermodynamic functions less than $\pm 1 \mathrm{cal} \mathrm{mol}^{-1} \mathrm{~K}^{-1}$ for the following classes of molecules (one to eight carbon atoms):

(1) Acyclic and cyclic alkanes, alkenes, and alkadienes.

(2) Substituted and unsubstituted aromatic compounds.

We have made progress but have not completed our treatment of bridged cyclic alkanes, alkenes, and alkadienes. Treatment of large molecules (nine and larger number of carbon atoms) affords special problems which must be addressed. First, the number of conformers that coexist increases rapidly as the number of carbon-carbon single bonds increases. For example, the number of rotomers ${ }^{23}$ of n-octane is 135 , while that for $n$-nonane is 378 and that for n-decane 1134. Clearly, the bulk of computer time for such large molecule calculations is likely to be spent on conformer search. Fortunately, the number of conformers for cylic molecules is smaller than the number for corresponding acycles; for example, just seven conformers contribute to the properties of cyclooctane. ${ }^{14}$ Second, large molecules, particularly acyclic molecules, are less rigid ${ }^{24}$ than smaller ones, and therefore uncertainties in the entropy calculation attributable to anharmonic vibrations arise. We propose to modify QCFF/PI to deal effectively with large molecules after we introduce oxygen and nitrogen heteroatomic capability into the program.

It is clear from the progress made so far that thermodynamic properties of many gasphase organic reactions can be determined with good accuracy without recourse to time- 
consuming, expensive laboratory work. As progress continues, the list of accessible reactions grows. That good results can be obtained by molecular mechanics for gas-phase reactions augurs well for similar reactions that occur in liquid phases, for if gas-phase reaction equilibria could not be predicted, there would be little hope for liquid phase reaction predictions.

\section{Experimental Studies:}

This portion of our studies provides experimental data for proper parameterization of predictive computation models. More specifically, the following experimental measurements have been carried out:

1. Energy of combustion of the Diels-Alder adduct of anthracene and maleic anhydride (DAAMA).

2. X-ray crystal structure of DAAMA.

3. Sublimation presslire of DAAMA.

4. Energies of combustion of 4-methyl-cyclohex-1-ene $(4 \mathrm{MCH})$ and 4-vinylcyclohex-1-ene (4VCH).

5. Vapor pressures and enthalpies of vaporization of 4-methyl-cyclohex-1-ene and 4-vinyl-cyclohex-1-ene.

A. Energy of Combustion of DAAMA: The purity of DAAMA, $\mathrm{C}_{18} \mathrm{H}_{12} \mathrm{O}_{3}$, was estimated by differential scanning calorimetry, nuclear magnetic resonance spectroscopy, infra-red spectroscopy, mass spectroscopy and elemental analysis.

A Parr 1241 automatic calorimeter and a Parr 1710 controller were used to measure energy of combustion of DAAMA (99.7) mole per cent pure). NBS certified benzoic acid (39i) was used for all calibration experiments. DAAMA was combusted in crystal form. Detailed discussions of the calorimeter and the combustion procedure are given in our recent 
publication. ${ }^{11}$ The combustion experiment results for DAAMA can also be found in our paper publication. ${ }^{11}$

B. X-Ray Crystal Structure of the DAAMA: Clear, colorless crystals of DAAMA were grown from ethyl acetate by slow cooling. A Nicolet R3m diffractometer was used to determine the X-ray structure of DAAMA.

The following were determined from the present crystallographic experiments: $\mathrm{C}_{18} \mathrm{H}_{12} \mathrm{O}_{3}$; monoclinic, $\mathrm{P} 2 / \mathrm{c}, \mathrm{a}=11.1317(66) \AA, \mathrm{b}=9.4194(46) \AA, \mathrm{c}=12.7234$ (67) $\AA, \alpha=90.0, \beta=103.857(47)^{\circ}, \gamma=90.0, V=1295.23 \AA^{3}, Z=4, D_{x}=1.41 \mathrm{~g} \cdot \mathrm{cm}^{-3}, \lambda$ $(\mathrm{Mo} \mathrm{K} \alpha)=0.7107 \AA, \mu=1.0 \mathrm{~cm}^{-1}, \mathrm{~F}(000)=575.93, \mathrm{~T}=153.15 \mathrm{~K}$.

The data were collected under Wyckoff scanning mode with index restrictions, $-19 \leq$ $\mathrm{h} \leq 19,0 \leq \mathrm{k} \leq 12,0 \leq 1 \leq 16$. Lorentz and polarization corrections were applied during data reduction; however, no absorption correction was necessary due to low absorption coefficient. Out of a total number of reflections of 2547,1976 unique reflections with $F_{0}>$ $2.5 \sigma\left(\mathrm{F}_{\mathrm{o}}\right)$ were observed.

The structure was solved by direct methods (RANT); The SHELXTL programs, run on a DG Eclipse S/140 computer, was used to perform all crystallographic computations. Anisoptropic thermal parameters were used for all non-H atoms. At convergence, the following figures of merit were observed: total number of least square parameters $=190$, data/parameters $=10.4, R=0.040, w R=0.0428, G O F=1.33, g=6.3 \times 10^{-4}$, slope of normal probability plot $=1.186,(\Delta \rho)_{\max }=0.22 \mathrm{e} \cdot \AA^{-3},(\Delta \rho)_{\min }=-0.23 \mathrm{e} \cdot \AA^{-3}$. Figure 2 shows the structure of DAAMA. The atomic coordinates are given in Table 8 . The bond lengths and angles are summarized in Tables 9 and 10, respectively.

C. Vapor Pressure and Enthalpy of Sublimation of DAAMA: A mass-loss-effusiontype apparatus was used to measure the vapor pressure of DAAMA. The enthalpy of sublimation of DAAMA could be derived from this measured vapor pressure of DAAMA. 
The effusion apparatus employed principles of Knudsen effusion. The sample mass that effused at an equilibrium temperature through a known orifice area was measured in a given time interval. Subsequently, the sample vapor pressure was computed from the following equation:

$$
\mathrm{p}=2255.26(\Delta \mathrm{w} / \mathrm{C} / \mathrm{a} / \mathrm{t})(\mathrm{T} / \mathrm{M})^{1 / 2}
$$

where $\mathrm{p}$ is the sample vapor pressure ( $\mathrm{Pa}) ; \Delta \mathrm{w}$, mass loss due to effusion $(\mathrm{g})$; $\mathrm{a}$, area of the effusion orifice $\left(\mathrm{cm}^{2}\right) ; t$, time $(\mathrm{s}) ; \mathrm{T}$, temperature $(\mathrm{K}) ; \mathrm{M}$, molar mass of the sample; and $\mathrm{C}$, Clausing factor.

Benzoic acid was used as a test sample for the effusion apparatus. Unfortunately, satisfactory results were not obtained, due to lack of in situ sample weighing capability and other limitations in the apparatus. However, an order of magnitude determination of the DAAMA vapor pressure was attempted with the existing apparatus. As estimated from some rough measurements and an exhaustive literature search, the vapor pressure of DAAMA was expected to lie in the $10^{-1}-10^{-3} \mathrm{~Pa}$ range corresponding to a temperature range of $373-473 \mathrm{~K}$. The possibility of using a gas saturation apparatus, similar to the one described by Bruno, ${ }^{25}$ is also being explored.

D. Energies of Combustion of $4 \mathrm{MCH}$ and $4 \mathrm{VCH}$ : The combustion reactions for $4 \mathrm{MCH}$ and $4 \mathrm{VCH}$ occur according to equations 5 and 6 , respectively:

$$
\begin{aligned}
& \mathrm{C}_{7} \mathrm{H}_{12}(\mathrm{l})+10 \mathrm{O}_{2}(\mathrm{~g})=7 \mathrm{CO}_{2}(\mathrm{~g})+6 \mathrm{H}_{2} \mathrm{O}(\mathrm{l}) \\
& \mathrm{C}_{8} \mathrm{H}_{12}(\mathrm{l})+11 \mathrm{O}_{2}(\mathrm{~g})=8 \mathrm{CO}_{2}(\mathrm{~g})+6 \mathrm{H}_{2} \mathrm{O}(\mathrm{l})
\end{aligned}
$$

A Parr 1241 automatic calorimeter and a Parr 1710 controller were used to measure energies of combustion of $4 \mathrm{MCH}$ and $4 \mathrm{VCH}$. The calorimeter was calibrated with the NIST certified benzoic acid (SRM 39i). The liquid cyclohexene samples were combusted in gelation capsules (Parr 3601). The energy of combustion of gelatin was measured to be 
- (202008.4 \pm 113.8$) \mathrm{J} \cdot \mathrm{g}^{-1}$. Fuse wire with a stated energy of combustion of $5857.6 \mathrm{~J}$ • $\mathrm{g}^{-1}$, was supplied by the Parr Instrument Co.

The following thermodynamic properties of $4 \mathrm{MCH}\left(\mathrm{C}_{7} \mathrm{H}_{12}\right)$ and $4 \mathrm{VCH}\left(\mathrm{C}_{8} \mathrm{H}_{12}\right)$ have been determined from the present combustion experiments:

$$
\begin{aligned}
& \Delta_{\mathrm{c}} \mathrm{u}_{\mathrm{m}}\left(\mathrm{C}_{7} \mathrm{H}_{12}, 1,298.15 \mathrm{~K}\right)=-(4380.7 \pm 11.2) \mathrm{kJ} \cdot \mathrm{mol}^{-1} \\
& \Delta_{\mathrm{c}} \mathrm{H}_{\mathrm{m}}{ }_{\mathrm{m}}\left(\mathrm{C}_{7} \mathrm{H}_{12}, 1,298.15 \mathrm{~K}\right)=-(4388.1 \pm 11.2) \mathrm{kJ} \cdot \mathrm{mol}^{-1} \\
& \Delta_{\mathrm{f}} \mathrm{H}_{\mathrm{m}}\left(\mathrm{C}_{7} \mathrm{H}_{12}, 1,298.15 \mathrm{~K}\right)=-(81.5 \pm 11.2) \mathrm{kJ} \cdot \mathrm{mol}^{-1} \\
& \Delta_{\mathrm{f}} \mathrm{H}_{\mathrm{m}}\left(\mathrm{C}_{7} \mathrm{H}_{12}, \mathrm{~g}, 298.15 \mathrm{~K}\right)=-(46.7 \pm 11.2) \mathrm{kJ} \cdot \mathrm{mol}^{-1} \\
& \Delta_{\mathrm{c}} \mathrm{u}_{\mathrm{m}}^{\cdot}\left(\mathrm{C}_{8} \mathrm{H}_{12}, 1,298.15 \mathrm{~K}\right)=-(4890.5 \pm 10.7) \mathrm{kJ} \cdot \mathrm{mol}^{-1} \\
& \Delta_{\mathrm{c}} \mathrm{H}_{\mathrm{m}}^{\cdot}\left(\mathrm{C}_{8} \mathrm{H}_{12}, 1,298.15 \mathrm{~K}\right)=-(4897.5 \pm 10.7) \mathrm{kJ} \cdot \mathrm{mol}^{-1} \\
& \Delta_{\mathrm{f}^{\prime}} \mathrm{H}_{\mathrm{m}}\left(\mathrm{C}_{8} \mathrm{H}_{12}, 1,298.15 \mathrm{~K}\right)=(34.8 \pm 10.7) \mathrm{kJ} \cdot \mathrm{mol}^{-1} \\
& \Delta_{\mathrm{f}} \mathrm{H}_{\mathrm{m}}{ }_{\mathrm{m}}\left(\mathrm{C}_{8} \mathrm{H}_{12}, \mathrm{~g}, 298.15 \mathrm{~K}\right)=(73.5 \pm 10.7) \mathrm{kJ} \cdot \mathrm{mol}^{-1}
\end{aligned}
$$

5. Vapor Pressures and Enthalpies of Vaporization of $4 \mathrm{MCH}$ and $4 \mathrm{VCH}$ : The vapor pressures of $4 \mathrm{MCH}$ and $4 \mathrm{VCH}$ were measured by the dynamic vapor pressure method (Figure 3). The temperature of the boiling sample was measured by an ASTM-certified thermometer, which could be read to the nearest $0.1 \mathrm{~K}$. The pressure was measured by an absolute mercury manometer which could be read to the nearest $13.2 \mathrm{~Pa}(0.1$ torr $)$. The vapor pressure data were fit by the simplest linear relationship: $\ln \mathrm{p}=\mathrm{A}+\mathrm{BT}^{-1}$, and the original data are plotted in Figures 4 and 5. The enthalpies of vaporization of $4 \mathrm{MCH}$ and $4 \mathrm{VCH}$, derived from these measured vapor pressure data by the Clausius-Clapeyron equation, are : $\Delta_{\text {vap }} \mathrm{H}^{\circ}{ }_{\mathrm{in}}\left(\mathrm{C}_{7} \mathrm{H}_{12}\right)=(34.8 \pm 0.1) \mathrm{kJ} \cdot \mathrm{mol}^{-1}$ and $\Delta_{\text {vap }} \mathrm{H}_{\mathrm{m}}^{\circ}\left(\mathrm{C}_{8} \mathrm{H}_{12}\right)=(38.7 \pm$ $0.1) \mathrm{kJ} \cdot \mathrm{mol}^{-1}$. 
Table 1. Refereed Publications Resulting from Work Under DOE Grant DE-FG0286ER 13582.

1. T. G. Lenz and J. D. Vaughan, J. Phys. Chem. 1989, 93, 1588.

2. T. G. Lenz and J. D. Vaughan, J. Phys. Chem. 1989, 93, 1592.

3. T. G. Lenz and J. D. Vaughan, J. Comput. Chem. 1990, 11, 351.

4. T. G. Lenz and J. D. Vaughan, Chem. Eng Sci. 1990, 45, 1755.

5. M. Kar, T. G. Lenz, and J. D. Vaughan, J. Chem. Thermodynamics 1992, 24, 151.

6. S. Ramachandran, T. G. Lenz, J. D. Vaughan and A. K. Rappé, Quantum Chemistry Program Exchange Library 1990. Program 593 and accompanying documentation. 
Table 2. Thermodynamic Functions and Zero-Point Energies of Various Hydrocarbons at $298.15 \mathrm{~K}^{\mathrm{d}}$

\begin{tabular}{|c|c|c|c|c|}
\hline Compound & $\mathrm{ZPE}^{\mathrm{a}}$ & $\mathrm{S}^{0 \mathrm{~b}}$ & $C p^{\circ b}$ & $\left(\mathrm{H}^{\mathrm{o}}-\mathrm{H}_{\mathrm{O}}^{\mathrm{O}}\right) / \mathrm{T}^{\mathrm{b}}$ \\
\hline propene & $\begin{array}{l}48.14 \\
48.29 \\
\end{array}$ & $\begin{array}{l}63.99 \\
63.80 \\
\end{array}$ & $\begin{array}{l}15.40 \\
15.27 \\
\end{array}$ & $\begin{array}{l}10.94 \\
10.86 \\
\end{array}$ \\
\hline $\begin{array}{ll}\text { trans-2-butene } & \\
& \text { ref. } 13 \\
\end{array}$ & 65.4 & $\begin{array}{l}70.47 \\
70.86\end{array}$ & $\begin{array}{l}20.59 \\
20.99\end{array}$ & $\begin{array}{l}13.74 \\
14.05\end{array}$ \\
\hline $\begin{array}{l}\text { cis-2-butene } \\
\text { ref. } 13\end{array}$ & $\overline{65.4}$ & $\begin{array}{l}71.30 \\
71.90\end{array}$ & $\begin{array}{l}18.66 \\
18.86\end{array}$ & $\begin{array}{l}12.96 \\
13.23\end{array}$ \\
\hline $\begin{array}{ll}\text { cyclopentene } & \\
& \text { ref. } 14\end{array}$ & $\begin{array}{l}70.38 \\
70.48\end{array}$ & $\begin{array}{l}69.91 \\
69.61\end{array}$ & $\begin{array}{l}20.01 \\
19.42\end{array}$ & $\begin{array}{l}12.14 \\
11.91\end{array}$ \\
\hline cyclohexene & $\begin{array}{l}88.53 \\
88.39\end{array}$ & $\begin{array}{l}73.88 \\
74.24\end{array}$ & $\begin{array}{l}24.14 \\
24.25\end{array}$ & $\begin{array}{l}13.66 \\
13.84\end{array}$ \\
\hline $\begin{aligned} \text { cycloheptene }{ }_{\text {S }}^{\mathrm{C}_{\text {ref. } 14}} & \\
& \end{aligned}$ & $\begin{array}{l}106.04 \\
106.05\end{array}$ & $\begin{array}{l}79.15 \\
78.72\end{array}$ & $\begin{array}{l}29.04 \\
28.78\end{array}$ & $\begin{array}{l}15.96 \\
15.81\end{array}$ \\
\hline $\begin{array}{r}\text { 1,3-cyclopentadiene } \\
\text { ref. } 14\end{array}$ & $\begin{array}{l}56.64 \\
56.06 \\
\end{array}$ & $\begin{array}{l}65.76 \\
65.52 \\
\end{array}$ & $\begin{array}{l}18.04 \\
18.01 \\
\end{array}$ & $\begin{array}{l}10.98 \\
10.85 \\
\end{array}$ \\
\hline $\begin{array}{r}\text { 1,3-cyclohexadiene } \\
\text { ref. } 14\end{array}$ & $\begin{array}{l}74.25 \\
73.94 \\
\end{array}$ & $\begin{array}{l}72.72 \\
72.52 \\
\end{array}$ & $\begin{array}{l}22.66 \\
22.51\end{array}$ & $\begin{array}{l}13.10 \\
13.03\end{array}$ \\
\hline $\begin{array}{r}\text { 1,3-cycloheptadiene } \\
\text { ref. } 14\end{array}$ & $\begin{array}{l}91.92 \\
91.71\end{array}$ & $\begin{array}{l}78.61 \\
77.78\end{array}$ & $\begin{array}{l}27.30 \\
27.33\end{array}$ & $\begin{array}{l}15.32 \\
15.20\end{array}$ \\
\hline $\begin{array}{r}\text { 1,3-butadiene-trans } \\
\text { ref. } 14\end{array}$ & $\begin{array}{l}51.43 \\
51.56\end{array}$ & $\begin{array}{l}66.51 \\
66.51\end{array}$ & $\begin{array}{l}18.26 \\
18.37\end{array}$ & $\begin{array}{l}12.01 \\
12.02\end{array}$ \\
\hline $\begin{array}{r}\text { 1,3-pentadiene-(E) } \\
\text { ref. } 14\end{array}$ & 68.73 & $\begin{array}{l}76.16 \\
76.40\end{array}$ & $\begin{array}{l}23.60 \\
24.70\end{array}$ & 15.14 \\
\hline benzene & $\begin{array}{l}61.11 \\
61.12 \\
\end{array}$ & $\begin{array}{l}64.59 \\
64.37 \\
\end{array}$ & $\begin{array}{l}19.88 \\
19.52 \\
\end{array}$ & 11.53 \\
\hline biphenyl & $\begin{array}{l}110.54^{c} \\
110.91^{c}\end{array}$ & $\begin{array}{l}93.01^{\mathrm{c}} \\
93.85\end{array}$ & $\begin{array}{l}37.74^{\mathrm{c}} \\
-\end{array}$ & $\begin{array}{l}21.38^{\mathrm{c}} \\
21.18^{\mathrm{c}}\end{array}$ \\
\hline naphthalene & $\begin{array}{l}89.82 \\
-\quad\end{array}$ & $\begin{array}{l}80.11 \\
80.25\end{array}$ & $\begin{array}{l}32.02 \\
31.68\end{array}$ & 16.88 \\
\hline $\begin{array}{r}\text { 1-methylnaphthalene } \\
\text { ref. } 13\end{array}$ & - & $\begin{array}{l}91.14 \\
90.21\end{array}$ & $\begin{array}{l}37.85 \\
38.13\end{array}$ & 20.43 \\
\hline norbornene & - & $\begin{array}{l}73.45 \\
74.31\end{array}$ & 25.04 & $\overline{13.27}$ \\
\hline norbornadiene & - & $\begin{array}{l}70.64 \\
70.65 \\
\end{array}$ & 23.55 & 12.61 \\
\hline
\end{tabular}
a. $\mathrm{kcal} \mathrm{mol} \mathrm{m}^{-1}$
b. cal mol-1 $\mathrm{K}^{-1}$
c. Not corrected for hindered internal rotation
d. Literature values are given on the second line (referenced) for each entry. 
Table 3. Modified QCFF/PI Parameters ${ }^{a, b, c}$

A. Bond Stretch: $E_{R}=C B 1\left(R-R_{0}\right)^{2}-E_{B}$

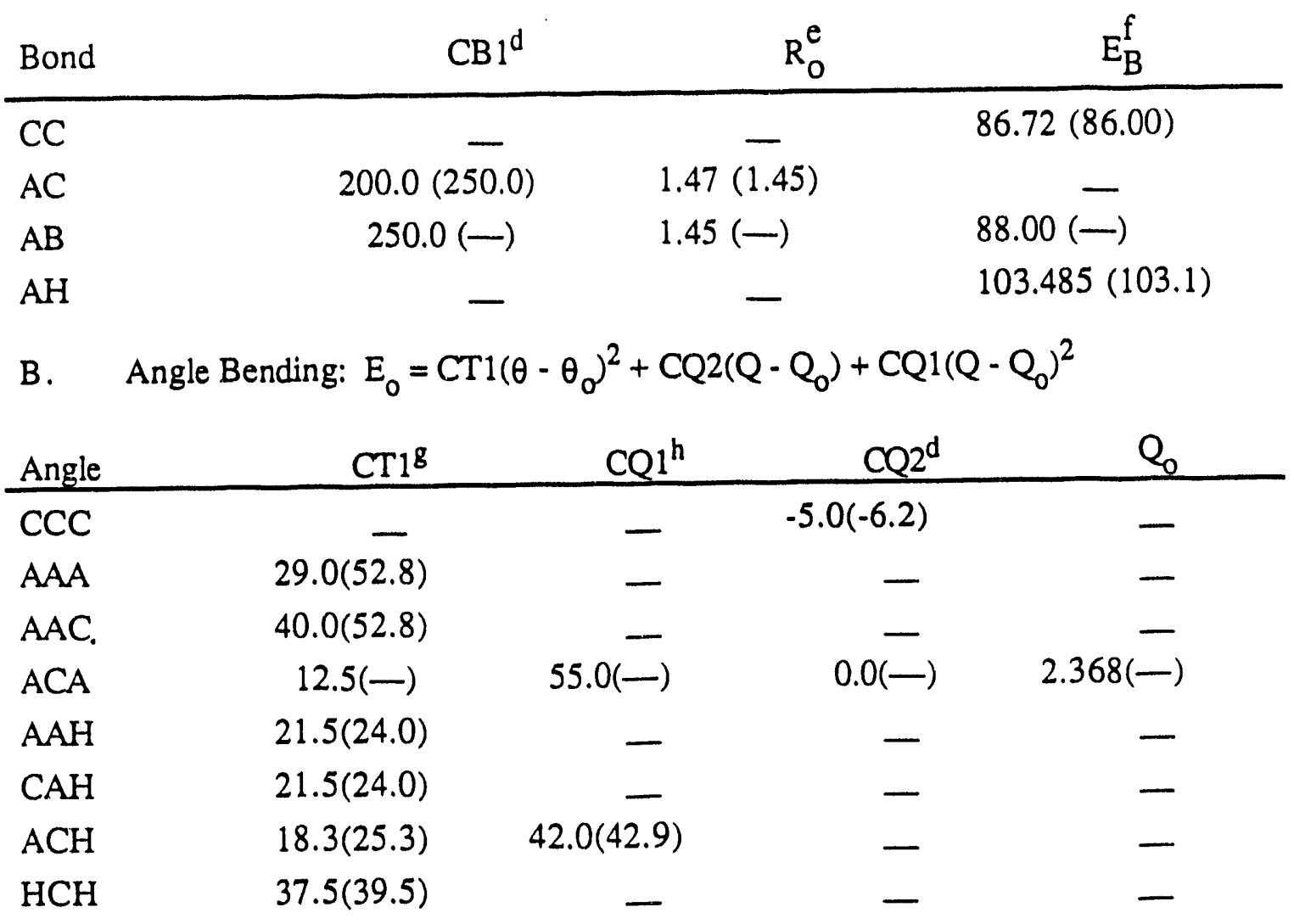

C. Torsion Energy: $E(\phi)=\operatorname{CP} 1(1+\cos n \phi)+C P 3 \cos \phi+C P 2\left(\theta_{1}-\theta_{0}\right)\left(\theta_{2}-\theta_{0}\right) \cos \phi$

\begin{tabular}{llcc} 
Angle & $\mathrm{CP}^{\mathrm{i}}$ & $\mathrm{CP} 2^{\mathrm{g}}$ & $\mathrm{CP}^{\mathrm{i}}$ \\
\hline XAAX & $1.80(2.54)$ & - & $0.0(2.30)$ \\
XACX & $-0.80(-0.90)$ & - & - \\
XCCX & $1.50(2.161)$ & $0.0(-2.30)$ & $-20.0(-9.50)$ \\
XBCX & $1.50(1.16)$ & $0.0(-2.30)$ & $-20.0(-9.50)$ \\
XABX & $-0.80(-)$ & $0.0(-)$ & $0.0(-)$
\end{tabular}

a. Original (default) parameters are enclosed by parentheses.

b. Blank spaces indicate no alteration, or, if enclosed by parentheses, that no value was assigned by the original authors. ${ }^{7}$

c. C represents saturated carbon $\left(\mathrm{Csp}^{3}\right), \mathrm{B}$ saturated methyl carbon, and A ethylenic carbon $\left(\mathrm{Csp}^{2}\right)$.

d. kcal mol ${ }^{-1} \AA^{-2}$, where $\AA$ refers to angstrom.

e. $R_{0}$ is the equilibrium bond length parameter; $\AA$

f. $\mathrm{kcal} \mathrm{mol}^{-1}$

g. $\mathrm{kcal} \mathrm{mol}^{-1}$ radian $^{-2}$

h. $Q$ and $Q_{0}$ are 1,3 -nonbonded distances ${ }^{7}$ in $\AA$; $C Q 2$ unit is $\mathrm{kcal} \mathrm{mol}^{-1} \AA^{-1}$.

i. $\mathrm{kcal} \mathrm{mol}^{-1}$. 
Table 4. Standard Enthalpies of Formation at $298.15 \mathrm{~K}$.

$\Delta \mathrm{H}_{\mathrm{f}}^{\mathrm{O}} \mathrm{kcal} / \mathrm{mol}$

\begin{tabular}{|c|c|c|c|}
\hline Compound & QCFF & $\mathrm{MMP}_{2}$ & Obsd. \\
\hline ethene & 12.50 & - & $12.50 \mathrm{~s}, 12.49 \mathrm{p}$ \\
\hline propene & 4.90 & 4.91 & $4.78 s, 4.88 p$ \\
\hline 1-butene-skew & -0.31 & -0.31 & \\
\hline 1-butene-syn & 0.43 & 0.76 & $0.0 \mathrm{~s}, 0.1 \pm 1.0 \mathrm{p}^{\mathrm{c}}$ \\
\hline 1-butene-anti & 1.69 & - & \\
\hline t-2-hutene & -2.72 & -2.47 & $-2.67 s,-2.72 p$ \\
\hline c-2-butene & -1.70 & -1.52 & $-1.67 s,-1.70 p$ \\
\hline 2-methylpropene & -4.025 & -3.86 & $-4.04 s,-4.04 p$ \\
\hline 2-methyl-2-butene & -10.14 & -9.86 & $-10.17 s,-9.99 p$ \\
\hline 2,3-dimethyl-2-butene & -15.93 & -15.84 & $-14.1 s,-16.3 p$ \\
\hline cyclopentene & 8.10 & - & $7.87 \mathrm{~s}, 8.10 \mathrm{p}$ \\
\hline cyclohexene & -1.19 & - & $-1.28 s,-1.2 p$ \\
\hline cycloheptene $\mathrm{C}_{5}$ & -2.43 & -2.96 & \\
\hline cycloheptene $C_{2}$ & -1.63 & -1.71 & $-2.25 \mathrm{~s},-2.2 \mathrm{p}$ \\
\hline 1,4-pentadiene-a & 24.81 & 25.85 & $25202524 n^{c}$ \\
\hline 1,4-pentadiene-s & 27.44 & 26.75 & $25.2 s, 25.24 \mathrm{p}$ \\
\hline 1,3-pentadiene & 32.15 & - & $32.1 \mathrm{p}$ \\
\hline 1,3-hexadiene & 25.38 & - & $25.9 \mathrm{~s}, 25.38 \mathrm{p}$ \\
\hline 1,3-heptadiene & 22.68 & 22.73 & $22.5 p$ \\
\hline benzene & 19.82 & - & $19.81 s, 19.7 p$ \\
\hline biphenyl & 43.06 & - & $43.52 \mathrm{~s}, 43.36 \mathrm{p}$ \\
\hline 1-methylnaphthalene & 27.96 & - & $27.93 \mathrm{~s}$ \\
\hline norbornane & -12.42 & -12.84 & $-13.10 p$ \\
\hline $\begin{array}{l}\text { bicyclononane } \\
\text { (chair-chair) }\end{array}$ & -30.65 & - & $-30.47 p$ \\
\hline
\end{tabular}

a. s refers to Stull et al., ref. 13, and p to Pedley et al., ref. 17.

b. Estimate, ref. 14.

c. Conformer mix. 
Table 5. Supplemental Torsional Potential Energy Functions

\begin{tabular}{|c|c|c|c|c|}
\hline$C X$ & CY & $\mathrm{CZ}$ & $\mathrm{CW}$ & Dihedral Angle \\
\hline-0.2000 & 0.0 & 0.0 & 0.0 & $\begin{array}{l}s p^{3}-s p^{2}-s p^{2}-s p^{3} \\
\text { (alkanes) }\end{array}$ \\
\hline-0.1317 & 1.0056 & -1.9108 & 1.2963 & $\begin{array}{l}s p^{2} \mathrm{sp}^{2} \mathrm{sp}^{3} \mathrm{sp}^{3} \\
\text { (alkanes, alkadienes) }\end{array}$ \\
\hline-4.2640 & 9.0192 & -9.6462 & 4.1649 & $\begin{array}{l}\mathrm{Xsp^{3 }} \mathrm{sp}^{3} \mathrm{Y}^{\mathrm{b}} \\
\text { (bridged cycloalkanes) }\end{array}$ \\
\hline
\end{tabular}

$F(\phi)=C X(C Y+\cos \phi)-C Z(1-\cos 2 \phi)(1+C W \cos \phi)+C X A(1-\cos \phi)$

\begin{tabular}{cccccl}
$\mathrm{CX}$ & $\mathrm{CY}$ & $\mathrm{CZ}$ & $\mathrm{CW}$ & $\mathrm{CXA}$ & Dihedral Angle \\
\hline 1.3605 & -0.1165 & 1.4832 & $\begin{array}{l}1.0^{\mathrm{c}} \\
1.5^{\mathrm{d}}\end{array}$ & $\begin{array}{l}0.0 \\
0.0\end{array}$ & $\begin{array}{l}\mathrm{sp}^{2} \mathrm{sp}^{2} \mathrm{sp}^{2} \mathrm{sp}^{2} \\
(1,3-d i e n e s)\end{array}$ \\
\hline 0.758 & 1.000 & 0.0 & 0.0 & -0.5836 & $\begin{array}{l}\mathrm{sp}^{2} \mathrm{sp}^{2} \mathrm{sp}^{2} \mathrm{sp}^{2} \\
\text { (aromatic hydrocarbons) }\end{array}$ \\
\hline
\end{tabular}
a. $\mathrm{kcal} \mathrm{mol}^{-1}$
b. $X$ refers to $\mathrm{Csp}^{2}$ or $\mathrm{Csp}^{3}$, and $\mathrm{Y}$ to a bridgehead $\mathrm{Csp}{ }^{3}$.
c. $80^{\circ}-180^{\circ}$.
d. $0^{\circ}-80^{\circ}$. 
Table 6. Standard Enthalpies of Formation at $298.15 \mathrm{~K}$ $\Delta \mathrm{H}_{\mathrm{f}}^{\mathrm{o}} \mathrm{kcal} / \mathrm{mol}^{-1}$

Compound

n-butane- $\mathrm{a}^{\mathrm{c}}$

n-butane-g ${ }^{c}$

n-butane $(\mathrm{a} \leftrightarrow \mathrm{g})$

n-pentane-a

n-hexane-a

n-heptane-a

2-methylbutane $\mathrm{C}_{1}$

2-methylbutane $C_{s}$

2-methylpentane

3-methylpentane

3-methylhexane

2,3-dimethylbutane-g

2,3-dimethylbutane- $s^{d}$

2,3-dimethylpentane-g

2,3-dimethylpentane-a

2,3,4-trimethylpentane

2,2-dimethylbutane

2,2,3-trimethylpentane

2,2,3-trimethylhexane

2,2,3,3-tetramethylbutane

cyclohexane

cycloheptane $\mathrm{TC}^{\mathrm{e}}$

cyclooctane
QCFF

$-30.53$

$-29.63$

$-30.14^{b}$

$-36.25$

$-42.00$

$-47.745$

$-36.96$

$-36.04$

$-42.84$

$-41.29$

$-47.32$

$-42.51$

$-42.43$

$-46.91$

$-46.46$

$-52.33$

$-44.27$

$-52.88$

$-58.57$

$-53.99$

$-29.75$

$-28.64$

$-30.25$
MMP2

$-30.51$

$-29.65$

$-29.87^{b}$

$-36.27$

$-42.05$

$-47.88$

$-36.90$

$-42.64$

$-41.41$

$-47.15$

$-42.58$

$-47.04$

$-46.57$

$-52.38$

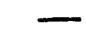

$-52.92$

$-58.68$

$-54.00$

$-29.53$

$-28.19$

$-29.50$
Obsd. $^{a}$

$-34.15 \mathrm{~s},-30.02 \dot{\mathrm{p}}$

$-44.48 s,-44.35 p$

$-53.99 \mathrm{~s},-53.91 \mathrm{p}$

$-29.43 \mathrm{~s},-29.49 \mathrm{p}$

$-28.52 \mathrm{~s},-28.25 \mathrm{p}$

$-30.06 s,-29.73 p$

a. s refers to Stull et al., ref. 13, and p to Pedley et al., ref. 17.

b. conformer mix.

c. a refers to anti configuration and $g$ to gauche configuration.

d. $s$ refers to symmetric configuration.

e. TC refers to twist chair configuration. 
Table 7. Effect of Internal Rotation: $500 \mathrm{~K}$ and $1000 \mathrm{~K}$

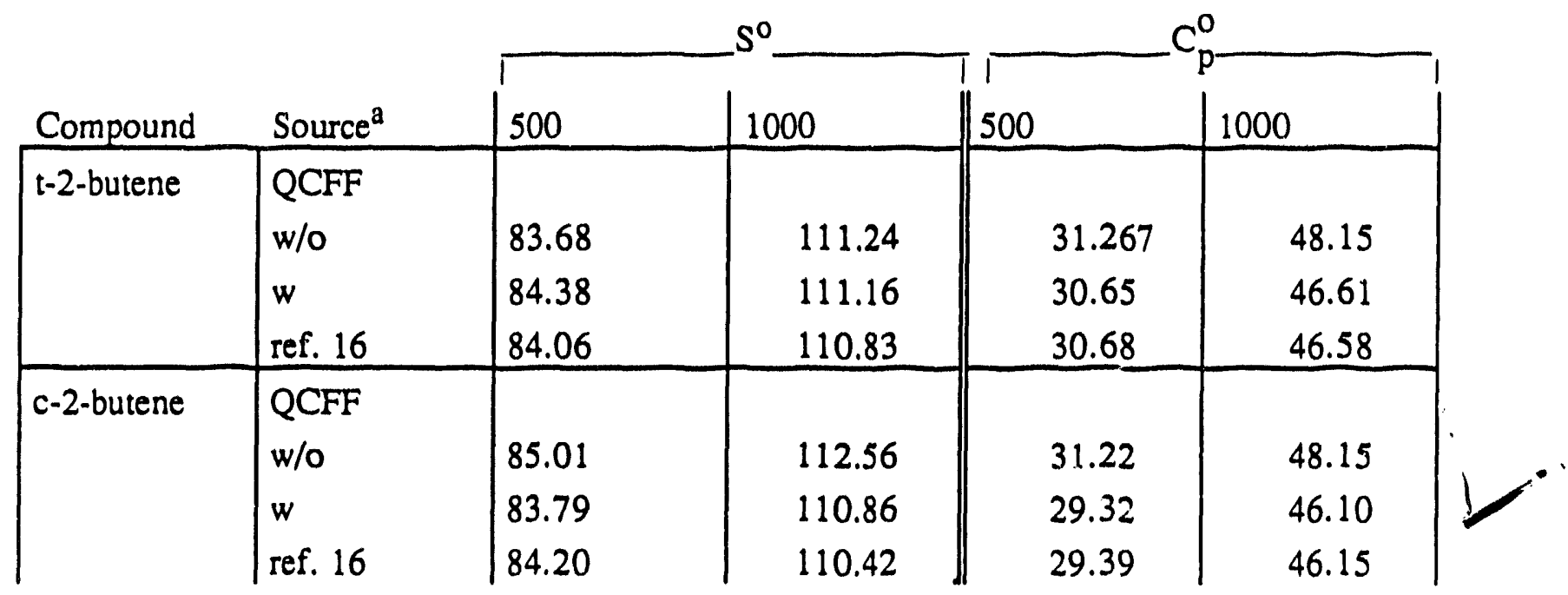

a. $\quad w / 0$ indicates hindered internal rotational contributions are not included; $w$ indicates they are.

b. $\quad \mathrm{cal} \mathrm{mol}^{-1} \mathrm{~K}^{-1}$. 
TABLE 8 Atomic coordinates $\left(\times 10^{4}\right)$ and isotropic thermal parameters $(\AA 2 \times 103)$ for DAAMA

\begin{tabular}{lcrrr} 
& $x$ & $y$ & \multicolumn{1}{l}{$z$} & $U^{*}$ \\
$\mathrm{O} 1$ & $8711(1)$ & $5280(1)$ & $1850(1)$ & $34(1)$ \\
$\mathrm{O} 2$ & $9199(1)$ & $6536(1)$ & $526(1)$ & $25(1)$ \\
$\mathrm{O} 3$ & $9560(1)$ & $8256(1)$ & $-558(1)$ & $29(1)$ \\
$\mathrm{C} 1$ & $7545(1)$ & $9690(2)$ & $2525(1)$ & $21(1)$ \\
$\mathrm{C} 2$ & $7343(1)$ & $10176(2)$ & $3489(1)$ & $24(1)$ \\
$\mathrm{C} 3$ & $7455(2)$ & $11623(2)$ & $3716(1)$ & $27(1)$ \\
$\mathrm{C} 4$ & $7776(1)$ & $12551(2)$ & $2988(1)$ & $25(1)$ \\
$\mathrm{C} 5$ & $7981(1)$ & $12063(2)$ & $2022(1)$ & $21(1)$ \\
$\mathrm{C} 6$ & $7851(1)$ & $10635(2)$ & $1787(1)$ & $19(1)$ \\
$\mathrm{C} 7$ & $8032(1)$ & $9927(2)$ & $773(1)$ & $18(1)$ \\
$\mathrm{C} 8$ & $6906(1)$ & $9023(2)$ & $312(1)$ & $19(1)$ \\
$\mathrm{C} 9$ & $6197(1)$ & $9056(2)$ & $-738(1)$ & $22(1)$ \\
$\mathrm{C} 10$ & $5221(1)$ & $8111(2)$ & $-1049(1)$ & $26(1)$ \\
$\mathrm{C} 11$ & $4964(2)$ & $7144(2)$ & $-320(1)$ & $27(1)$ \\
$\mathrm{C} 12$ & $5668(2)$ & $7113(2)$ & $737(1)$ & $24(1)$ \\
$\mathrm{C} 13$ & $6633(1)$ & $8059(2)$ & $1054(1)$ & $20(1)$ \\
$\mathrm{C} 14$ & $7507(1)$ & $8162(2)$ & $2160(1)$ & $20(1)$ \\
$\mathrm{C} 15$ & $8832(1)$ & $7855(2)$ & $2002(1)$ & $20(1)$ \\
$\mathrm{C} 16$ & $8900(2)$ & $6417(2)$ & $1516(1)$ & $24(1)$ \\
$\mathrm{C} 17$ & $9331(1)$ & $7945(2)$ & $276(1)$ & $21(1)$ \\
$\mathrm{C} 18$ & $9131(1)$ & $8881(2)$ & $1170(1)$ & $18(1)$
\end{tabular}

* Equivalent isotropic $U$ defined as one third of the trace of the orthogonalized $U_{i j}$ tensor. 
TABLE 9 Bond lengths $(\AA)$ for DAAMA

$\begin{array}{llll}\mathrm{O} 1-\mathrm{C} 16 & 1.192(2) & \mathrm{O} 2-\mathrm{C} 16 & 1.385(2) \\ \mathrm{O} 2-\mathrm{C} 17 & 1.384(2) & \mathrm{O}-\mathrm{C} 17 & 1.189(2) \\ \mathrm{C} 1-\mathrm{C} 2 & 1.381(2) & \mathrm{C} 1-\mathrm{C} 6 & 1.397(2) \\ \mathrm{C} 1-\mathrm{C} 14 & 1.513(2) & \mathrm{C} 2-\mathrm{C} 3 & 1.395(2) \\ \mathrm{C} 3-\mathrm{C} 4 & 1.385(3) & \mathrm{C} 4-\mathrm{C} 5 & 1.385(3) \\ \mathrm{C} 5-\mathrm{C} 6 & 1.381(2) & \mathrm{C} 6-\mathrm{C} 7 & 1.511(2) \\ \mathrm{C} 7-\mathrm{C} 8 & 1.517(2) & \mathrm{C} 7-\mathrm{C} 18 & 1.562(2) \\ \mathrm{C} 8-\mathrm{C} 9 & 1.384(2) & \mathrm{C} 8-\mathrm{C} 13 & 1.397(2) \\ \mathrm{C} 9-\mathrm{C} 10 & 1.390(2) & \mathrm{C} 10-\mathrm{C} 11 & 1.381(3) \\ \mathrm{C} 11-\mathrm{C} 12 & 1.390(2) & \mathrm{C} 12-\mathrm{C} 13 & 1.384(2) \\ \mathrm{C} 13-\mathrm{C} 14 & 1.516(2) & \mathrm{C} 14-\mathrm{C} 15 & 1.565(2) \\ \mathrm{C} 15-\mathrm{C} 16 & 1.502(2) & \mathrm{C} 15-\mathrm{C} 18 & 1.531(2) \\ \mathrm{C} 17-\mathrm{C} 18 & 1.500(2) & & \end{array}$


TABLE 10 Bond angles $\left({ }^{\circ}\right)$ for DAAMA

$\begin{array}{llll}\mathrm{C} 16-\mathrm{O} 2-\mathrm{C} 17 & 110.5(1) & \mathrm{C} 2-\mathrm{C} 1-\mathrm{C} 6 & 120.4(2) \\ \mathrm{C} 2-\mathrm{C} 1-\mathrm{C} 14 & 126.3(2) & \mathrm{C} 6-\mathrm{C} 1-\mathrm{C} 14 & 113.3(1) \\ \mathrm{C} 1-\mathrm{C} 2-\mathrm{C} 3 & 119.0(2) & \mathrm{C} 2-\mathrm{C} 3-\mathrm{C} 4 & 120.3(2) \\ \mathrm{C} 3-\mathrm{C} 4-\mathrm{C} 5 & 120.7(2) & \mathrm{C} 4-\mathrm{C} 5-\mathrm{C} 6 & 119.2(2) \\ \mathrm{C} 1-\mathrm{C} 6-\mathrm{C} 5 & 120.4(2) & \mathrm{C} 1-\mathrm{C} 6-\mathrm{C} 7 & 113.5(1) \\ \mathrm{C} 5-\mathrm{C} 6-\mathrm{C} 7 & 126.1(2) & \mathrm{C} 6-\mathrm{C} 7-\mathrm{C} 8 & 108.3(1) \\ \mathrm{C} 6-\mathrm{C} 7-\mathrm{C} 18 & 104.9(1) & \mathrm{C} 8-\mathrm{C} 7-\mathrm{C} 18 & 106.5(1) \\ \mathrm{C} 7-\mathrm{C} 8-\mathrm{C} 9 & 126.4(1) & \mathrm{C} 7-\mathrm{C} 8-\mathrm{C} 13 & 113.4(1) \\ \mathrm{C} 9-\mathrm{C} 8-\mathrm{C} 13 & 120.2(1) & \mathrm{C} 8-\mathrm{C} 9-\mathrm{C} 10 & 119.3(2) \\ \mathrm{C} 9-\mathrm{C} 10-\mathrm{C} 11 & 120.4(1) & \mathrm{C} 10-\mathrm{C} 11-\mathrm{C} 12 & 120.4(2) \\ \mathrm{C} 11-\mathrm{C} 12-\mathrm{C} 13 & 119.4(2) & \mathrm{C} 8-\mathrm{C} 13-\mathrm{C} 12 & 120.1(1) \\ \mathrm{C} 8-\mathrm{C} 13-\mathrm{C} 14 & 113.2(1) & \mathrm{C} 12-\mathrm{C} 13-\mathrm{C} 14 & 126.6(2) \\ \mathrm{C} 1-\mathrm{C} 14-\mathrm{C} 13 & 108.2(1) & \mathrm{C} 1-\mathrm{C} 14-\mathrm{C} 15 & 104.9(1) \\ \mathrm{C} 13-\mathrm{C} 14-\mathrm{C} 15 & 106.6(1) & \mathrm{C} 14-\mathrm{C} 15-\mathrm{C} 16 & 111.2(1) \\ \mathrm{C} 14-\mathrm{C} 15-\mathrm{C} 18 & 109.9(1) & \mathrm{C} 16-\mathrm{C} 15-\mathrm{C} 18 & 104.2(1) \\ \mathrm{O} 1-\mathrm{C} 16-\mathrm{O} 2 & 120.0(2) & \mathrm{O} 1-\mathrm{C} 16-\mathrm{C} 15 & 129.5(2) \\ \mathrm{O} 2-\mathrm{C} 16-\mathrm{C} 15 & 110.5(1) & \mathrm{O} 2-\mathrm{C} 17-\mathrm{O} 3 & 120.1(1) \\ \mathrm{O} 2-\mathrm{C} 17-\mathrm{C} 18 & 110.3(1) & \mathrm{O} 3-\mathrm{C} 17-\mathrm{C} 18 & 129.6(2) \\ \mathrm{C} 7-\mathrm{C} 18-\mathrm{C} 15 & 109.9(1) & \mathrm{C} 7-\mathrm{C} 18-\mathrm{C} 17 & 111.9(1) \\ \mathrm{C} 15-\mathrm{C} 18-\mathrm{C} 17 & 104.6(1) & & \end{array}$




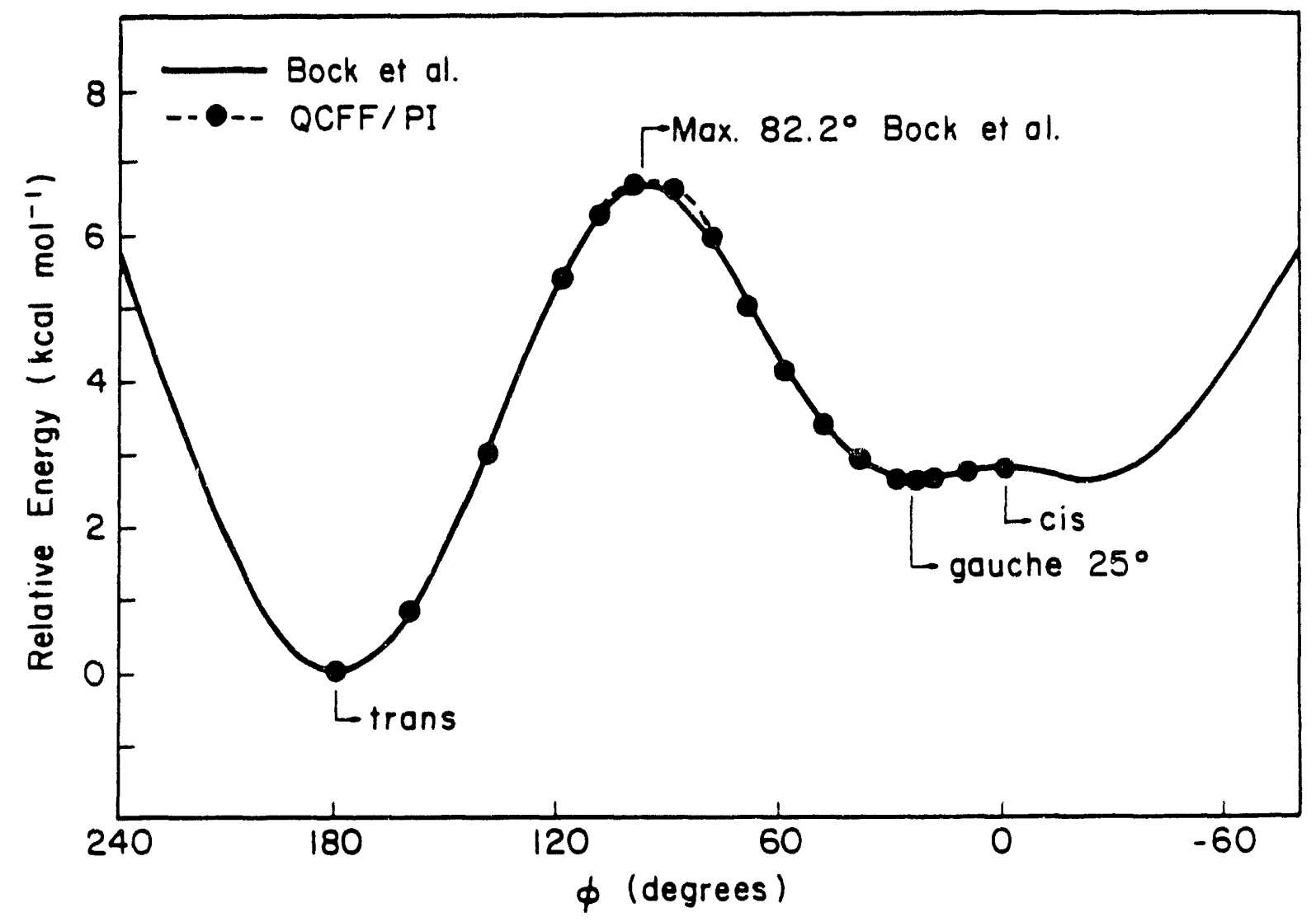

FIGURE 1 Torsional Profile of 1,3-butadiene 


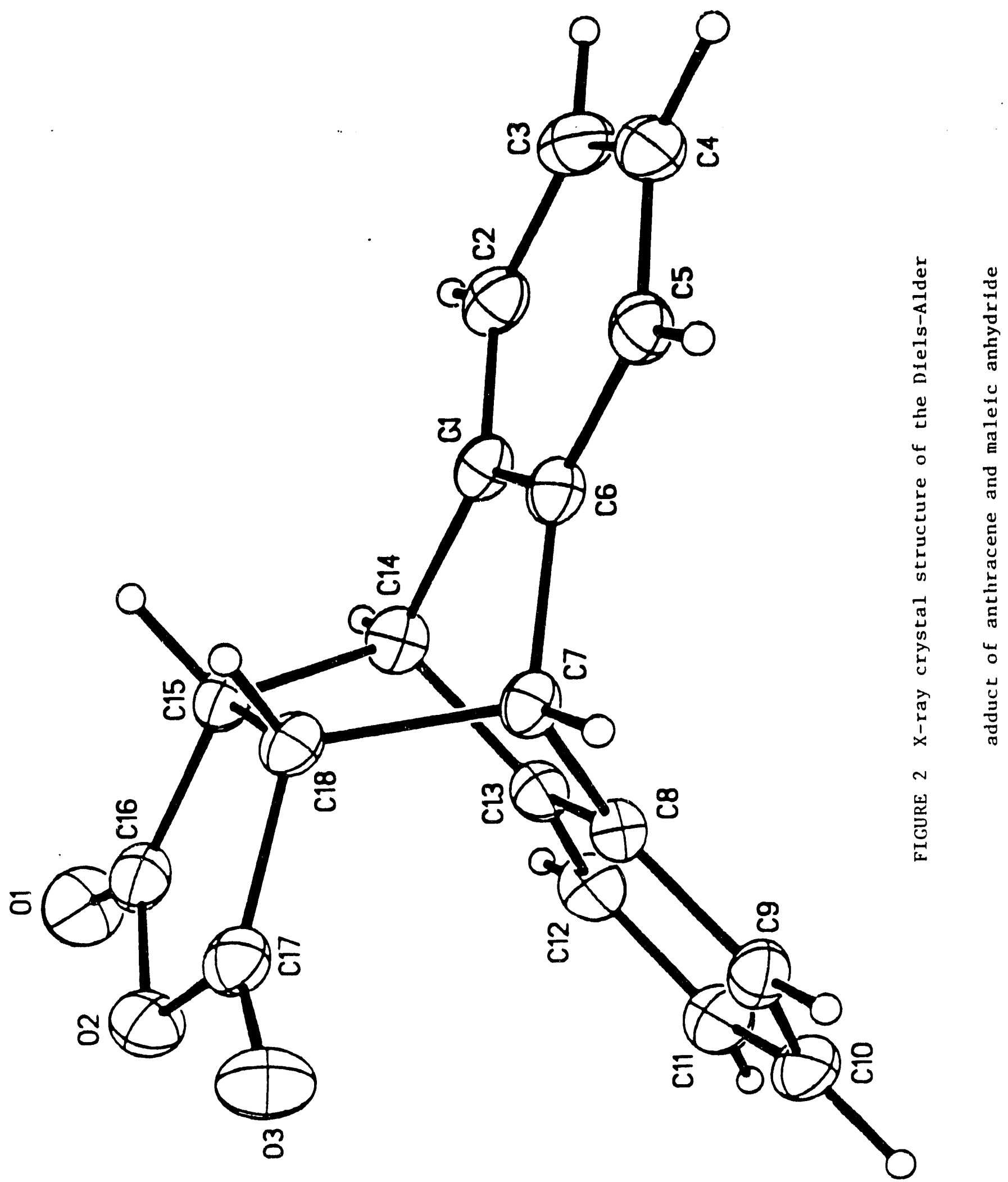




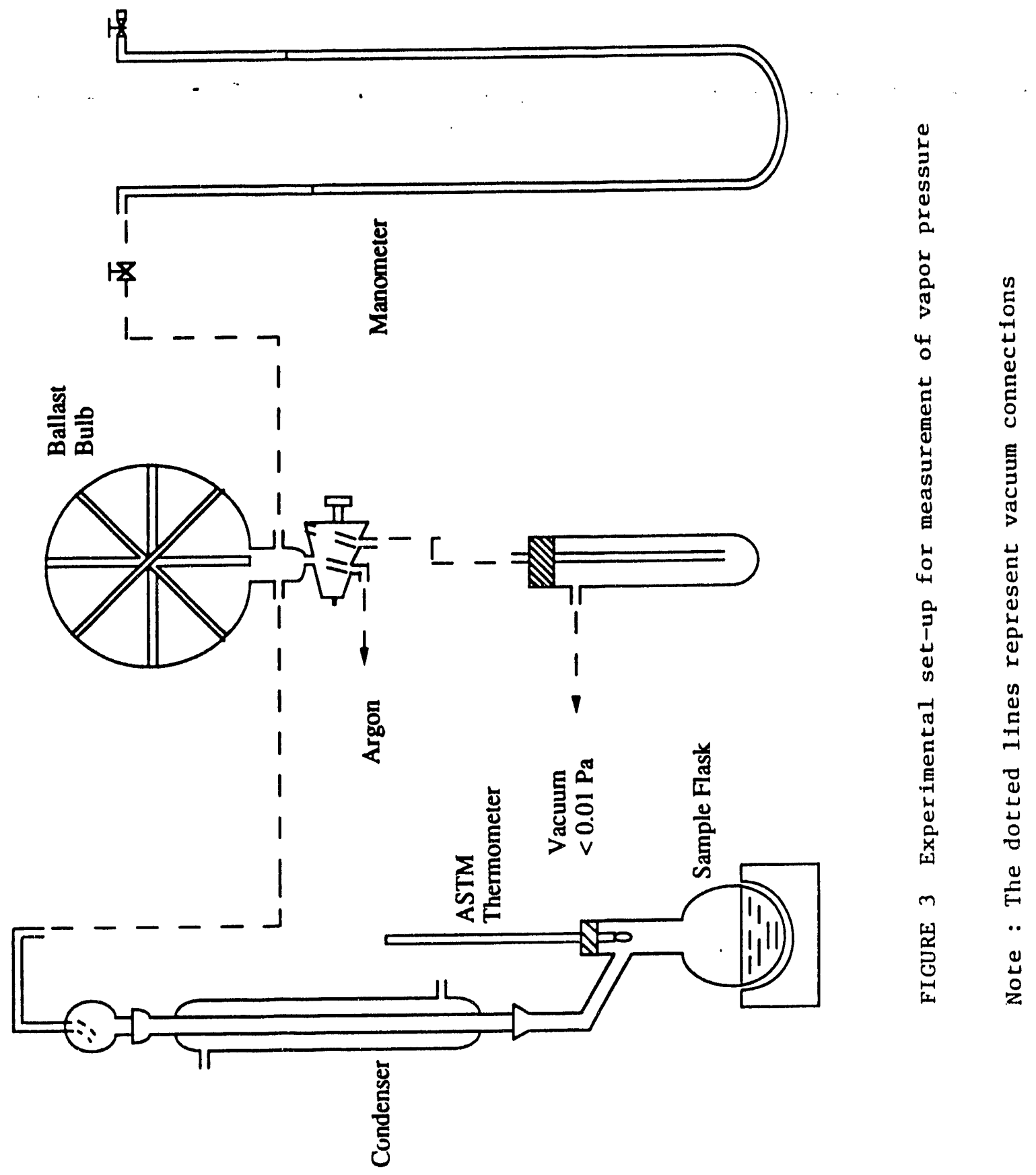




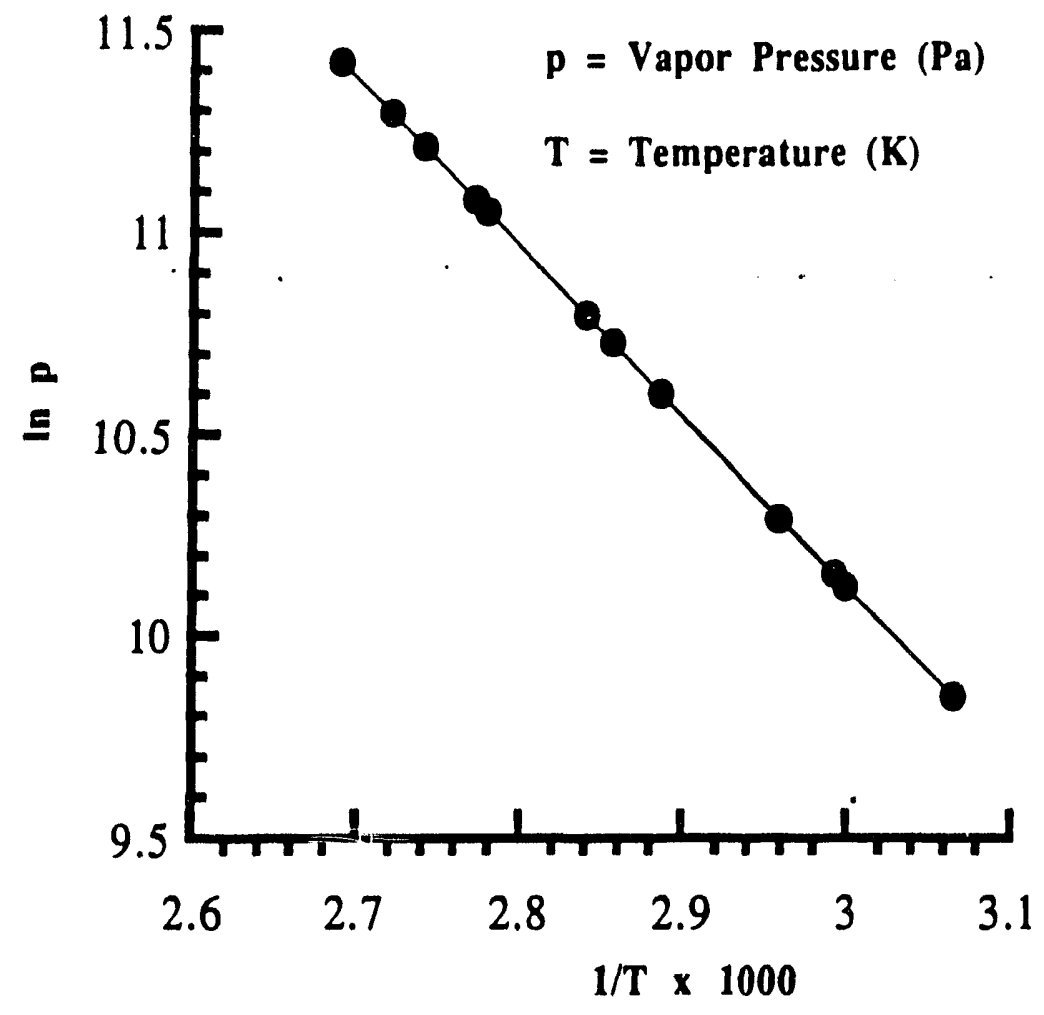

FIGURE 4 Vapor pressure - temperature plot for

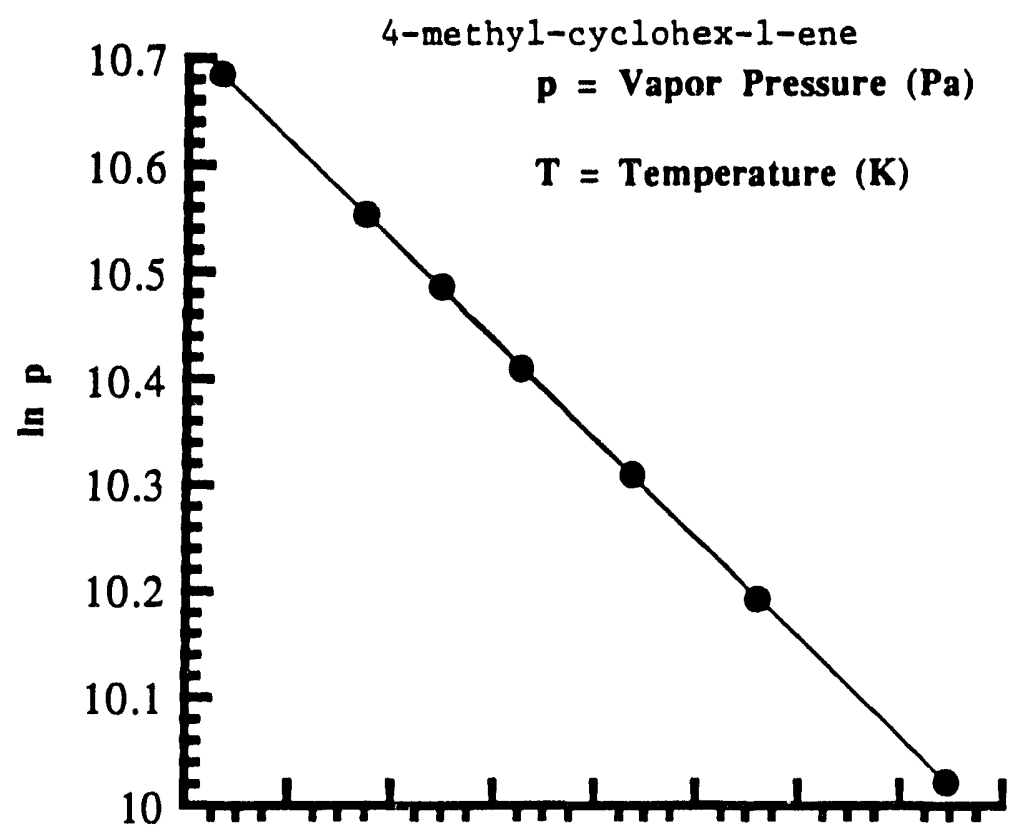

$\begin{array}{lllllllll}2.68 & 2.7 & 2.72 & 2.74 & 2.76 & 2.78 & 2.8 & 2.82 & 2.84\end{array}$

$1 / \mathrm{T} \times 1000$

FIGURE 5 Vapor pressure - temperature plot for 


\section{$\underline{\text { References }}$}

1. A. Wassermann, Diels-Alder Reactions, Elsevier, 1965.

2. T. G. Lenz and J. D. Vaughan, J. Phys. Chem. 1989, 93, 1592.

3. T. G. Lenz and J. D. Vaughan, J. Comput. Chem. 1990, 11, 351.

4. T. G. Lenz and J. D. Vaughan, Chem. Eng. Sci. 1990, 45, 1755.

5. S. Chang, D. McNally, S. Shary-Tehrany, M. Hickey, and R. H. Boyd, J. Am.Chem. Soc. 1970, 92, 3109.

6. N. L. Allinger and H. L. Flanagan, J. Comput. Chem. 1983, 4, 399.

7. A. Warshel and M. Karplus, J. Am. Chem. Soc. 1972, 94, 5612.

8. The original QCFF/PI program could calculate viliational frequencies, but not thermodynamic functions.

9. $\Delta \mathrm{G}^{0}=-\mathrm{RT} \ln \mathrm{K}_{\mathrm{a}}$.

10. a. A. G. Turnbull and H. S. Hull, Aust. J. Chem. 1968, 21, 1789.

b. H. S. Hull, A. F. Reid, and A. G. Turnbull, ibid. 1965, 18, 249.

11. M. Kar, T. G. Lenz, and J. D. Vaughan, J. Chem. Thermodynamics 1992, 24, 151.

12. T. G. Lenz and J. D. Vaughan, Composite Technical Progress Report for DOE Grant DE-FG02-86ER 13582 for the period 7/1/86 to 6/30/89.

13. D. R. Stull, E. F. Westrum, Jr., and G. C. Sinke, The Chemical Thermodynamics of Organic Compounds, Wiley, 1966.

14. D. V. Dorofeeva, L. V. Gurvich, and V. S. Jorish, J. Phys. Chem. Ref. Data 1986, 15, 437.

15. J. E. Caton and E. R. Lippincott, Spectrochim. Acto 1959, 15, 627.

16. C. W. Bock, P. George, M. Trachtman, and M. Zanger, J.C.S. Perkin II 1979, 26.

17. J. B. Pedley, R. D. Naylor, and S. P. Kirby, Thermochemical Data of Organic Compounds, second ed., Chapman and Hall, 1986.

18. J. E. Kilpatrick and K. S. Pitzer, J. Res. N.B.S. 1946, 37, 163.

19. J. O. Halford, J. Chem. Phys. 1947, 15, 364.

20. K. S. Pitzer and W. D. Guinn, Ibid. 1942, 10, 428.

21. R. B. Scott, C. H. Meyers, R. D. Rands, F. G. Brickwedde, and N. Bakkedahl, J. Res. N.B.S., 1945, 35, 39.

22. J. G. Aston, G. Szasz, H. L. Wooley, and F. G. Brickwedde, J. Chem. Phys. 1946, 14, 67.

23. D. Farasiu, P. Walter, and K. Sheils, J. Comp. Chem. 1989, $10,520$.

24. M. J. S. Dewar and George P. Ford, J. Am. Chem. Soc. 1977, 99, 7822. 
25. T. J. Bruno, Supercritical Fluid Technology: Reviews in Modern Theory and Applications. T. J. Bruno and J. F. Ely, editors. CRC Press: Boca Raton. 1991, Chapter 7. 


\section{Appendix}

2-Methyl-1.3 Butadiene (Isoprene): The supplemental torsion potential function used for butadiene (equation 4 in section II.B.) was further testẹd for the case where a methyl group was substituted in the central $\mathrm{sp}^{2}$ carbon of butadiene. The potential function of internal rotation for 2-methyl-1,3 butadiene (isoprene) was calculated with the QCFF/PI program. Isoprene consists of trans- and sterioisomeric gauche- conformers, with a relative energy difference of $2.6 \mathrm{kcal} \mathrm{mol}^{-1}$ between the trans- and gauche-conformers. ${ }^{1}$ The QCFF/PI calculated torsion profile of isoprene was found to be in excellent agreement with the one obtained by Panchenko et al (figure A). ${ }^{1}$ The QCFF/PI program was also used to calculate thermodynamic properties: $\Delta \mathrm{H}_{\mathrm{f}}^{0}, \mathrm{~S}^{0}$ and $\mathrm{C}_{\mathrm{p}}^{0}$, for isoprene. The QCFF calculated values and the corresponding experimental values are compared in table $\mathrm{A}$, and the agreement is found to be excellent.

Table A. Thermodynamic Properties of Isoprene at $298.15 \mathrm{~K}$.

2-Methyl-1,3-butadiene ${ }^{\mathrm{a}}$

\begin{tabular}{|c|c|c|c|c|c|c|}
\hline & & $\Delta \mathrm{H}_{\mathrm{f}}^{\mathrm{o}^{\mathrm{b}}}$ & $\mathrm{S}^{\mathrm{O}^{\mathrm{c}}}$ & $C_{p}^{O^{C}}$ & $\mathrm{ZPE}^{\mathrm{b}}$ & $\left(\mathrm{H}_{\mathrm{T}^{\mathrm{O}}}^{\mathrm{o}} \mathrm{H}_{\mathrm{O}}^{\mathrm{j}}\right) / \mathrm{T}^{\mathrm{c}}$ \\
\hline $\begin{array}{r}\overline{\mathrm{QCFF}} \\
\mathrm{m}\end{array}$ & $\begin{array}{c}\mathrm{t} \\
\mathrm{g} \\
\mathrm{mix}\end{array}$ & $\begin{array}{l}17.96 \\
20.48 \\
18.03\end{array}$ & $\begin{array}{l}74.95 \\
75.05 \\
75.21\end{array}$ & $\begin{array}{l}23.48 \\
23.48 \\
23.48\end{array}$ & $\begin{array}{l}68.63 \\
68.62\end{array}$ & $\begin{array}{l}14.54 \\
14.58 \\
14.54\end{array}$ \\
\hline Lit. & & $18.00^{d}$ & $75.44 \mathrm{e}^{\mathrm{e}}$ & $25.00 \mathrm{e}$ & & \\
\hline
\end{tabular}

a. $t$ refers to the trans- conformer, $g$ to gauche-, and mix to the equilibrium mixture of trans- and gauche- conformers.

b. kcal mol-1.

c. cal $\mathrm{mol}^{-1} \mathrm{~K}^{-1}$.

d. Reference 2 .

e. Reference 3. 


\section{References}

1. Panchenko, Yu. N.; Pupyshev, V. I.; Abramenkov, A. V.; Traetteberg, M.; Cyvin, S.

J J. Mol. Struct. 1985, 130, 355.

2. Pedley, J. B.; Naylor, R. D.; Kirby, S. P. Thermochemical Data of Organic

Compounds. 2nd ed. Chapman and Hall:New York. 1986.

3. Stull, D. R.; Westrum, Jr., E. F.; Sinke, G. C. The Chemical Thermodynamics of Organic Compounds. John Wiley and Sons, Inc.: New York. 1969. 


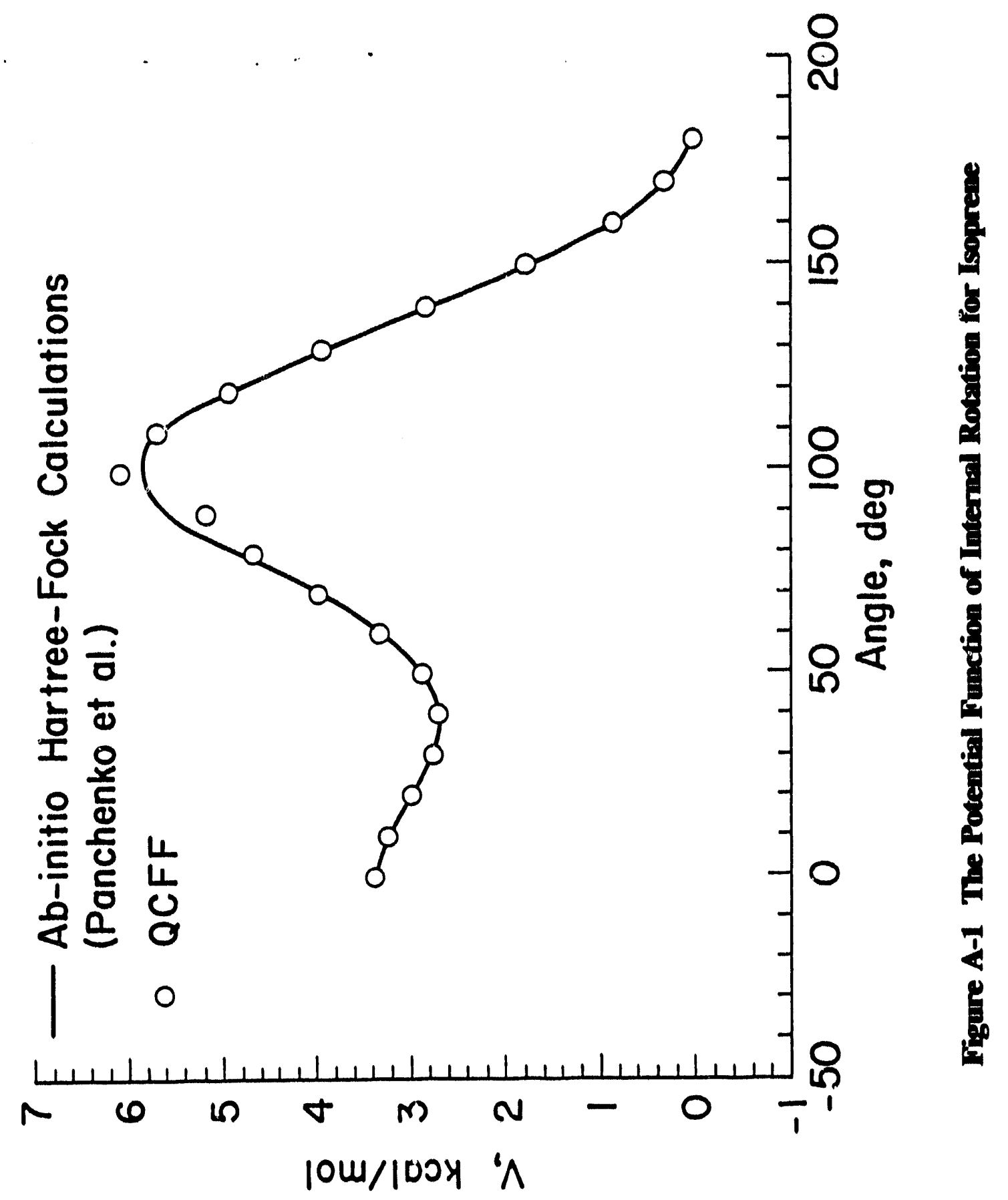



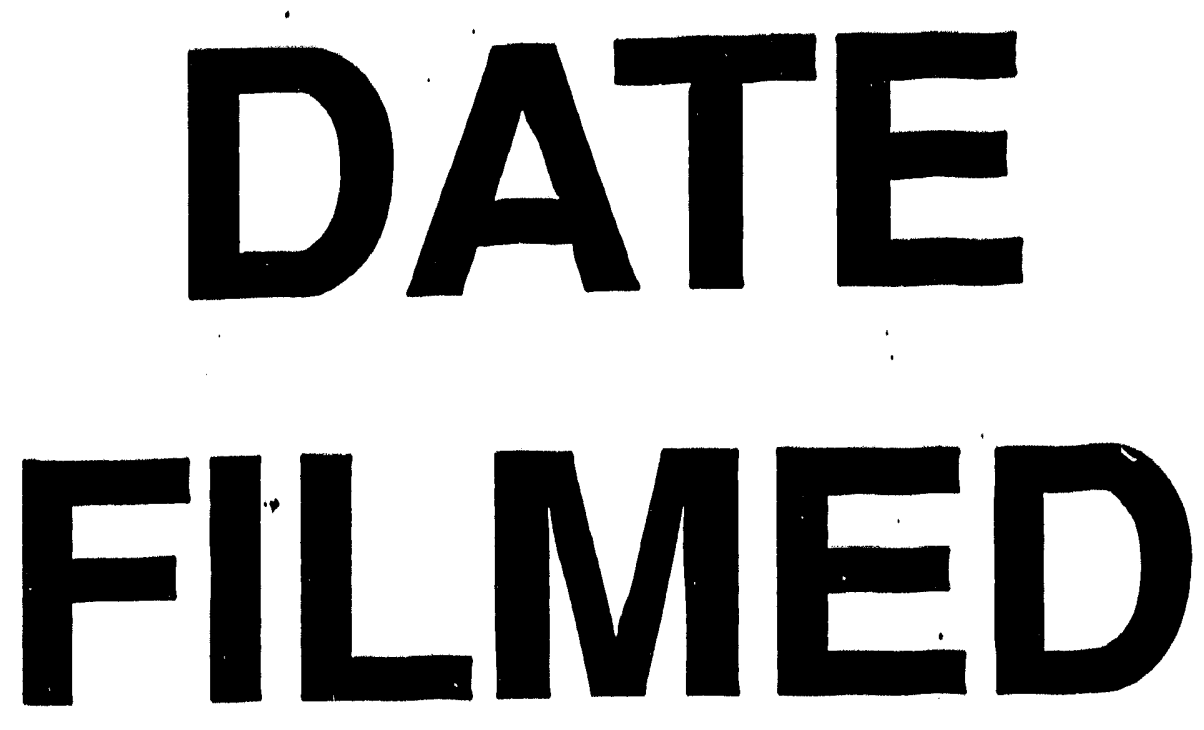

$12 / 6 / 93$
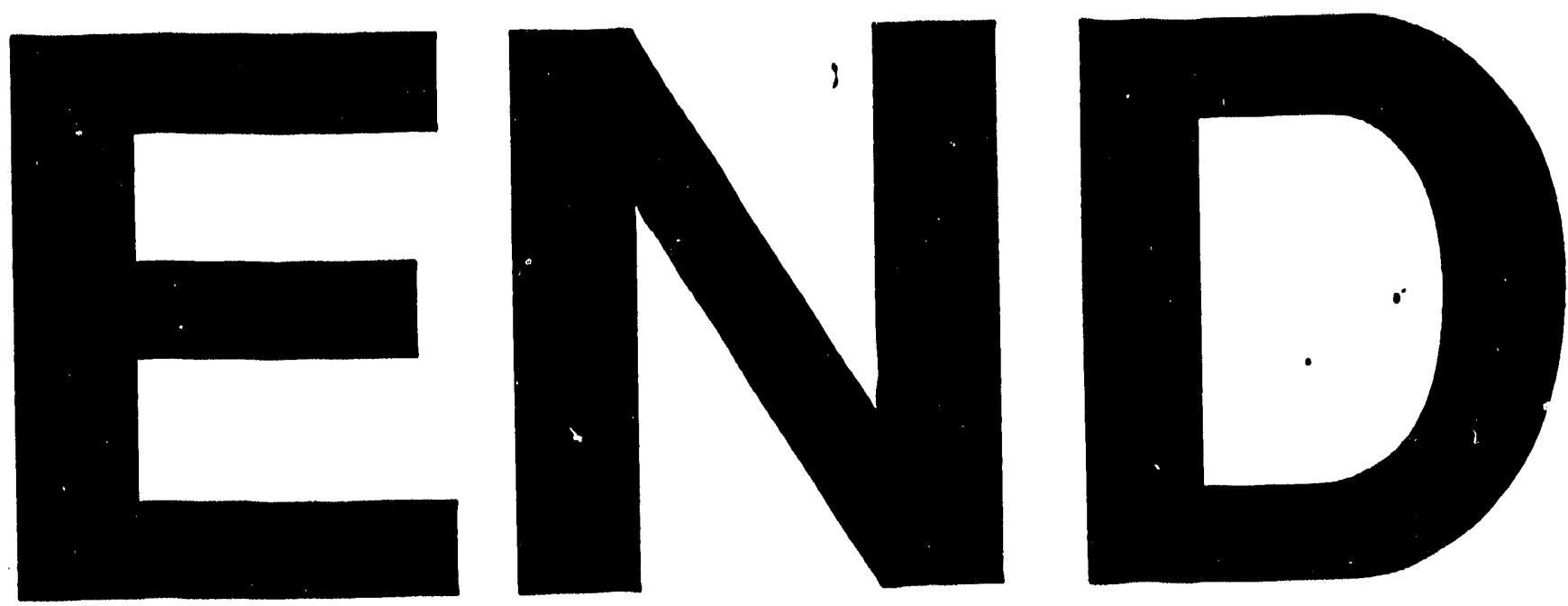